The University of Maine

\title{
DigitalCommons@UMaine
}

Earth Science Faculty Scholarship

Earth Sciences

9-1-1998

\section{Antarctic Glacial History Since the Last Glacial Maximum: An Overview of the Record on Land}

Ólafur Ingólfsson

Christian Hjort

Paul A. Berkman

Svante Björck

Eric Colhoun

See next page for additional authors

Follow this and additional works at: https://digitalcommons.library.umaine.edu/ers_facpub

Part of the Earth Sciences Commons

\section{Repository Citation}

Ingólfsson, Ólafur; Hjort, Christian; Berkman, Paul A.; Björck, Svante; Colhoun, Eric; Goodwin, Ian D.; Hall, Brenda; Hirakawa, Kazuomi; Melles, Martin; Möller, Per; and Prentice, Michael L., "Antarctic Glacial History Since the Last Glacial Maximum: An Overview of the Record on Land" (1998). Earth Science Faculty Scholarship. 125.

https://digitalcommons.library.umaine.edu/ers_facpub/125

This Conference Proceeding is brought to you for free and open access by DigitalCommons@UMaine. It has been accepted for inclusion in Earth Science Faculty Scholarship by an authorized administrator of DigitalCommons@UMaine. For more information, please contact

um.library.technical.services@maine.edu. 
Authors

Ólafur Ingólfsson, Christian Hjort, Paul A. Berkman, Svante Björck, Eric Colhoun, Ian D. Goodwin, Brenda Hall, Kazuomi Hirakawa, Martin Melles, Per Möller, and Michael L. Prentice 


\title{
Antarctic glacial history since the Last Glacial Maximum: an overview of the record on land
}

\section{ÓLAFUR INGÓLFSSON', CHRISTIAN HJORT², PAUL A. BERKMAN ${ }^{3}$, SVANTE BJÖRCK $^{4}$, ERIC COLHOUN 5 , IAN D. GOODWIN ${ }^{6}$, BRENDA HALL ${ }^{7}$, KAZUOMI HIRAKAWA $^{8}$, MARTIN MELLES $^{9}$, PER MÖLLER ${ }^{2}$ and MICHAEL L. PRENTICE ${ }^{10}$}

\author{
'Göteborg University, Earth Sciences Centre, Box 460, S-405 30 Göteborg, Sweden \\ ${ }^{2}$ Lund University, Department of Quaternary Geology, Sölvegatan 13, S-223 62 Lund, Sweden \\ ${ }^{3}$ Byrd Polar Research Center, The Ohio State University, 108 Scott Hall, 1090 Carmack Road, Columbus, OH 432I0, USA \\ ${ }^{4}$ Geological Institute, University of Copenhagen, Oster Voldgade 10, DK-1350 Copenhagen K, Denmark \\ ${ }^{5}$ Department of Geography and Environmental Science, University of Newcastle, Callaghan, Newcastle, NSW 2308, Australia \\ 'Antarctic CRC and SCAR Global Change Programme, GPO Box 252-80, Hobart, TAS 7001, Australia \\ 'Department of Geological Sciences and Institute for Quaternary Studies, University of Maine at Orono, Orono, ME 04469-5790. USA \\ ${ }^{8}$ Graduate School of Environmental Earth Sciences, Hokkaido University, N10 W5, Sapporo, 060 Japan \\ "Alfred Wegener Institute, Research Unit Potsdam, Telegrafenberg A 43, D-14473 Potsdam. Germany \\ ${ }^{10}$ Institute for the Study of Earth. Oceans and Space (EOS), 362 Morse Hall, University of New Hampshire, Durham,
}

NH 03824-3525, USA

\begin{abstract}
This overview examines available circum-Antarctic glacial history archives on land, related to developments after the Last Glacial Maximum (LGM). It considers the glacial-stratigraphic and morphologic records and also biostratigraphical information from moss banks, lake sediments and penguin rookeries, with some reference to relevant glacial marine records. It is concluded that Holocene environmental development in Antarctica differed from that in the Northern Hemisphere. The initial deglaciation of the shelf areas surrounding Antarctica took place before $10000{ }^{14} \mathrm{C}$ yrs before present (BP), and was controlled by rising global sea level. This was followed by the deglaciation of some presently ice-free inner shelf and land areas between 10000 and $8000 \mathrm{yr} \mathrm{BP}$. Continued deglaciation occurred gradually between $8000 \mathrm{yr} \mathrm{BP}$ and $5000 \mathrm{yr} \mathrm{BP}$. MidHolocene glacial readvances are recorded from various sites around Antarctica. There are strong indications of a circum-Antarctic climate warmer than today $4700-2000 \mathrm{yr}$ BP. The best dated records from the Antarctic Peninsula and coastal Victoria Land suggest climatic optimums there from 4000-3000 yr BP and 3600-2600 yr BP, respectively. Thereafter Neoglacial readvances are recorded. Relatively limited glacial expansions in Antarctica during the past few hundred years correlate with the Little Ice Age in the Northern Hemisphere.
\end{abstract}

Received 18 December 1997, accepted 2 June 1998

Key words: Antarctica, deglaciation, ${ }^{14} \mathrm{C}$ chronology, climate optimum, Holocene

\section{Introduction}

The Antarctic Ice Sheet, presently containing 25-30 million $\mathrm{km}^{3}$ of ice (Lovering \& Prescott 1979, Drewry et al. 1982), is the worlds' largest glacial system and has existed intermittently for 30-40 million years, since the mid-Tertiary (Hambrey et al. 1989, Birkenmajer 1987, 1991, Barrett et al. 1991). It has been suggested that the Antarctic Ice Sheet has existed close to its present stable configuration for the past 14 million years (Shackleton \& Kennett 1975, Sugden et al. 1993), although parts of the ice sheet have fluctuated substantially during the Quaternary.

The influences of Antarctic Ice Sheet fluctuations in the Quaternary history of global climate are not yet well understood. More than $98 \%$ of the Antarctic continent is today covered by glacier ice, and the potential on land for obtaining high-resolution geological data pertaining to its glacial history is poor. A fundamental question, given the suggested long-term stable glacial system in Antarctica, is what caused the glacial fluctuations observed in the records? Antarctic glaciers respond both to global sea level changes, mainly driven by Northern Hemisphere glacial fluctuations, and to Southern Hemisphere climate changes. A good understanding of the Late Quaternary glacial and climate history of Antarctica will also constrain the contribution of Antarctic ice to the global sea-level and marine oxygenisotope records, and is important for understanding the relative timing of climate changes between the polar hemispheres (Denton et al. 1989, Clapperton \& Sugden 1990, Andrews 1992, Colhoun et al. 1992, Moriwaki et al. 1992, Quilty 1992).

Studies of Late Quaternary climate changes in Antarctica have been focused on ice-core and marine records, as a consequence of the scarcity of chronologically well constrained geological data on land. However, the last two decades have seen increasingly more sophisticated data from ice free areas in Antarctica (Fig. 1), based on glacial stratigraphical and morphological investigations, studies of 


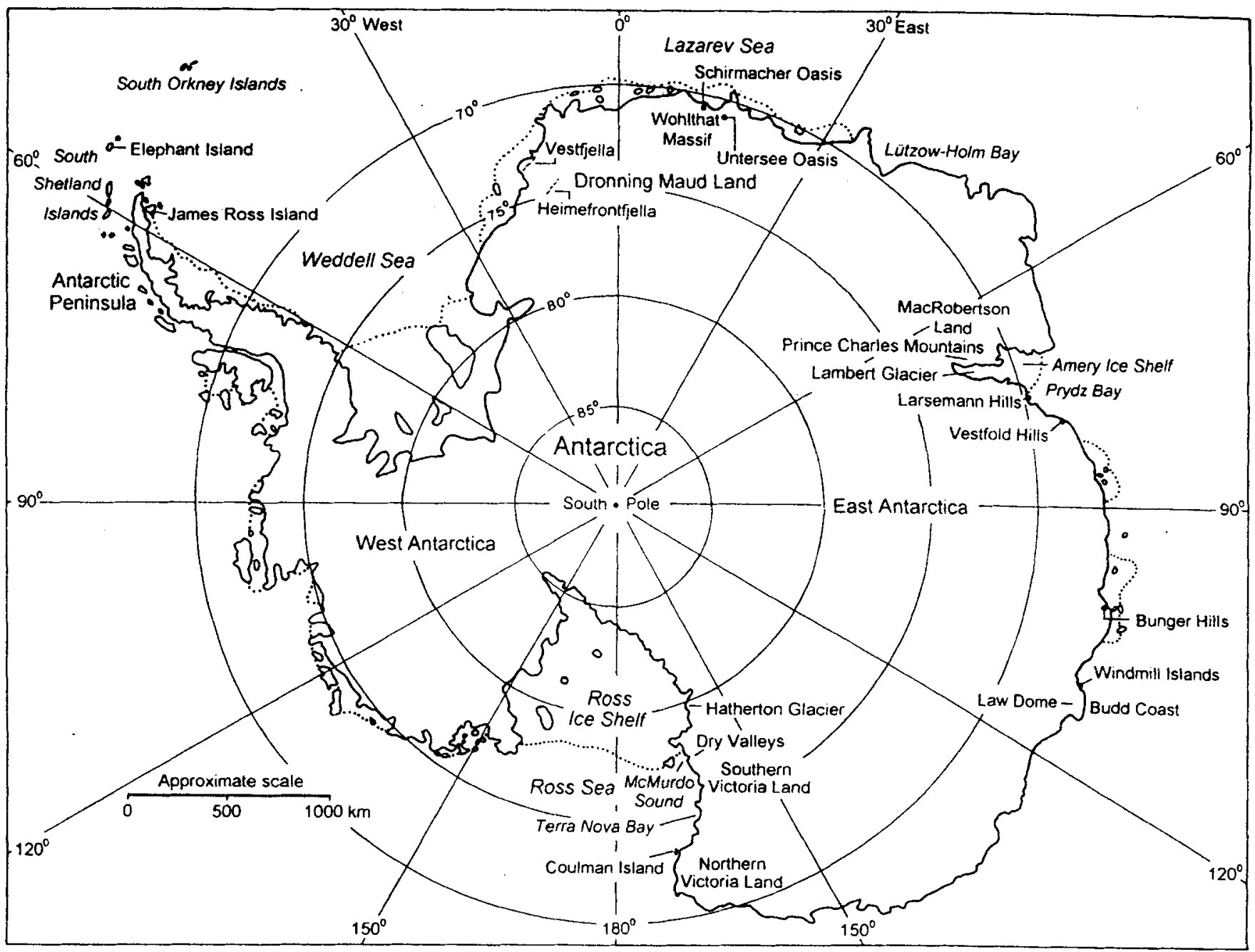

Fig. 1. Map of Antarctica showing the locations of the ice-free areas discussed in the text.

lake sediment and moss-bank cores, and of fossil penguin rookeries. Our knowledge primarily concerns the "postglacial" developments, i.e. from the Late Wisconsinan and Holocene, because those geological archives, although few and far between, are the best preserved.

The purpose of this paper is to review the glacial history in Antarctica since the Last Glacial Maximum (LGM), as seen through the geological data on land. The focus of the paper is on three major aspects:

a) Can a circum-Antarctic glacial history pattern be identified?

b) What does the record imply about the control of glaciation by sea-level and by climate?

c) What is the relative timing of the deglaciation in Antarctica and of the Northern Hemisphere large ice sheets?

\section{Chronological control}

The age control on glacial and climatic events since the LGM in Antarctica is primarily through ${ }^{14} \mathrm{C}$ dating. Marine materials like mollusc shells, marine mammal bones, penguin remains (bones, guano-debris) and snow petrel stomach oil or nest deposits are one source of datable materials. Terrestrial and lacustrine materials like mosses, lake sediment bulk samples, microbial mats, aquatic mosses and algal flakes have also been widely used for constraining environmental changes in time. Both marine and terrestrial/lacustrine materials often yield ages that appear too old in comparison with the conventional terrestrial-based radiocarbon time-scale (Björck et al. 1991 a, Gordon \& Harkness 1992). A requirement for understanding the dynamics of the Antarctic glacial system is to have a reliable chronology for both terrestrial and marine materials. 


\section{Dating terrestrial materials}

Radiocarbon dates on terrestrial materials are mainly from peat deposits, primarily mosses, in moss-banks on the islands off the Antarctic Peninsula (e.g. Fenton 1980, Birkenmajer et al. 1985, Björck et al. 199 la, 199 lb) and bulk sediments, microbial mats, aquatic mosses and algal flakes from Antarctic lake sediments and deltas (e.g. Stuiver et al. 1981, Pickard \& Seppelt 1984, Pickard et al. 1986, Zale \& Karlén 1989, Mäusbacher et al. 1989, Schmidt et al. 1990, Ingólfsson et al. 1992, Björck et al. 1993, 1996a).

Samples of moss-bank peat on Elephant Island (Fig. 1) have been found to give some of the most reliable ${ }^{14} \mathrm{C}$ ages in Antarctica (Björck et al. 1991 a, 1991b), and are thus optimal for constructing a ${ }^{14} \mathrm{C}$ chronology for environmental changes in the Antarctic Peninsula region for the past 5000 years. There is a balance between atmospheric carbon content and the intake of carbon by the mosses; old groundwater or carbon from the bedrock will not influence the carbon content of the mosses and contamination by down-growth of roots from plants living on the surface is minimal. There are difficulties in correlating the peat sequences to other archives (glacial stratigraphical sections and lake sediment sequences), but Björck et al. (1991c, 1991d) were able to correlate between moss-bank deposits and lake sediments in the Antarctic Peninsula region, using tephrostratigraphy, thus gaining an important chronological control for the lake sediment archives.

There are a number of sources of contamination when dating bulk sediments, microbial mats, aquatic mosses or algal flakes from Antarctic lake basins, often causing ages that are too old (e.g. Adamson \& Pickard 1986, Stuiver et al. 1981, Squyres et al. 1991, Björck et al. 1991a, Melles et al. 1994, Zale 1994):

a) Old groundwater or an input of glacial meltwater depleted in ${ }^{14} \mathrm{C}$, contaminating the submerged flora, can be a serious problem. Adamson \& Pickard (1986) and Stuiver et al. (1981) found that the correction needed for reservoir effects in freshwater algae is $450-700$ yrs.

b) Reduced gas exchange with the atmosphere due to a long (in extreme cases perennial or decadal) duration of the ice cover in lake and marine environments may lead to much older radiocarbon ages. This effect was described by Weiss et al. (1979) for the Weddell Sea and by Melles et al. (1997) for the marine basins (epishelf lakes) of Bunger Hills (Fig. 1). In the latter paper, modern reservoir effects of more than 2000 years were estimated, considerably higher than the marine reservoir effect of 1300 years estimated for the Vestfold Hills area (Adamson \& Pickard 1986).

c) Contamination by the marine reservoir effect through input from sea mammals and birds to lake basins (Björck et al. 199 la, Zale 1994).

d) Supply of old carbon from soils or weathered carbon- bearing rocks. Stuiver et al. (1981) described two ${ }^{14} \mathrm{C}$ dates from the same delta bed in southern Victoria Land. one from terrestrial algae, the other from a well preserved valve of the scallop Adamussium colbecki. The shell date was $5050 \pm 50 \mathrm{yr}$ BP (corrected by $1300{ }^{14} \mathrm{C}$ yr for marine reservoir age) and the algae $5930 \pm 200 \mathrm{yr} \mathrm{BP}$. which Stuiver et al. (1981) thought could reflect contamination by carbonate from local marble bedrock.

e) Continuous erosion of lake bottom surface sediments due to bottom-freezing in winter, or oxidation of these surface sediments during periods of desiccation, are processes which could lead to erroneous ${ }^{14} \mathrm{C}$ dates (Björck et al. 1991a).

f) Recycling of old carbon in stratified Antarctic lakes (Squyres et al. 1991).

g) Longevity of organisms may also play a role. Some Antarctic freshwater and terrestrial algae can survive long periods of desiccation and repeated freeze-thaw cycles (Vincent et al. 1993). Cryptoendolithic algae in suitable rock types in Antarctica are thought to have very slow turnover times, on the order of 10000 to $17000 \mathrm{yrs}$ (Nienow \& Friedmann 1993, Johnson \& Vestal 1991). These algae can be released to the ground when the rock erodes and then be blown or washed into other stratigraphic archives.

Radiocarbon dates for organic remains (microbial mats, algae, water mosses) in sediment cores sampled from the present Lake Hoare in Taylor Valley, McMurdo Dry Valleys, southern Victoria Land (Fig. 1), revealed that there can be large contamination problems (Squyres et al. 1991). These were expressed as very old ages of surface sediments (varying between 2000 and $6000{ }^{14} \mathrm{C}$ yrs) and samples obtained from depth in the cores yielding ages similar or younger than the surface material. Squyres et al. (1991) concluded that ${ }^{14} \mathrm{C}$ dates of Lake Hoare sediments were of limited value because of the high degree of contamination, and pointed out that probably the source carbon, which the organisms fix, is old, and that relatively long-term recycling of carbon in the lake could contribute to old apparent ${ }^{14} \mathrm{C}$ dates. A similar explanation is possible for ${ }^{14} \mathrm{C}$ ages of 24000 and $35700 \mathrm{yr} \mathrm{BP}$ from the base of marine inlet and lake cores in Bunger Hills, East Antarctica (Melles et al. 1997). In the fresh-water Lake Untersee (Dronning Maud Land, East Antarctica (Fig. 1)), a thick, perennial lake ice cover probably leads to a reservoir effect on radiocarbon dates as high as 11000 years (M. Schwab, personal communication 1998).

Björck et al. (1991a, 1991d) concluded that the causes of erroneous ages often seem to be a combination of different contamination sources and processes and that great caution is needed when ${ }^{14} \mathrm{C}$ dates on Antarctic lacustrine samples are interpreted and evaluated. A primary control for the reliability of the dates is the stratigraphic consistency in the dated sequence. In addition, the $\partial^{13} \mathrm{C}$-value should always be 
measured and used to correct the ${ }^{14} \mathrm{C} /{ }^{12} \mathrm{C}$ relationship. In some cases, the reported age could be incorrect by hundreds of years without such a correction (Björck et al. 199la). Dates on aquatic moss samples, extracted from the bulk sediments, appear to be more reliable than dates on the bulk sediments themselves, or on algae. Björck et al. (1991d) found that out of 14 radiocarbon dates from a lake basin on Livingston Island, in the South Shetland Islands, only three determinations could be judged reliable, after controlling the dates by tephrochronological cross-correlations. Two of these were on aquatic mosses.

\section{Dating marine materials}

Radiocarbon concentration in the Southern Ocean is dominated by the upwelling of deep water from the Northern Hem isphere at the Antarctic Divergence. Deepwater is depleted in ${ }^{14} \mathrm{C}$, and although mixing with "younger" surface water south of the Antarctic Convergence occurs, marine species which live in those waters have apparent radiocarbon ages that are older than 1000-1200 yrs (Broecker 1963, Björck et al. 1991a, Gordon \& Harkness 1992). Other factors which influence spatial and temporal variability in the Antarctic radiocarbon reservoir are inputs of ${ }^{14} \mathrm{C}$ depleted $\mathrm{CO}_{2}$ from melting ice, regional differences in the upwelling around Antarctica, perennial sea ice cover and local freshwater inputs into nearshore marine basins (Omoto 1983, Domack et al. 1989, Melles et al. 1994, Melles et al. 1997).

In the geological literature on Antarctica, different authors have taken different approaches to the marine reservoir correction. For example, Sugden \& John (1973), Clapperton \& Sugden (1982, 1988), Payne et al. (1989), Hansom \& Flint (1989) and Clapperton (1990) subtracted 750 years from their Antarctic Peninsula radiocarbon dates, whereas Barsch \& Mäusbacher (1986), working on the South Shetland Islands (Fig. 1) used an envelope of 850-1300 yrs. Ingólfsson et al. (1992) and Hjort et al. (1997) applied a sea correction of 1200 yrs, while Pudsey et al. (1994) used a reservoir correction of 1500 yrs. In East Antarctica, Adamson \& Pickard (1986), Colhoun \& Adamson (1992a) and Fitzsimons \& Colhoun (1995) used a reservoir correction of 1300 years when dealing with the Late Quaternary glacial history in the Vestfold Hills and Bunger Hills areas in East Antarctica, while Hayashi \& Yoshida (1994), working in the Lützow-Holm Bay area (Fig. 1), suggested a correction of 1100 years. Verkulich \& Hiller $(1994){ }^{14} \mathrm{C}$ dated stomach oil deposits in snow petrel colonies in Bunger Hills. They based their chronology for petrel colonization on conventional ${ }^{14} \mathrm{C}$ dates, but stated that a reservoir correction of 1300 years probably was appropriate. In the Victoria Land/Ross Sea area (Fig. 1), Stuiver et al. (1981) and Denton et al. (1989) based their chronology on uncorrected ${ }^{14} \mathrm{C}$ dates. Likewise, Baroni \& Orombelli (1991) used conventional dates for their deglaciation chronology for Terra Nova Bay, but calibrated the conventional ages when bracketing a relative sea level curve for the area. Baroni \&
Orombelli (1994a) presented both uncorrected conventional and calibrated ${ }^{14} \mathrm{C}$ chronologies when dealing with the Holocene environmental history of Victoria Land, but Baroni \& Orombelli (1994b) based their chronology of Holocene glacier variations in Terra Nova Bay on calibrated ${ }^{14} \mathrm{C}$ dates. Colhoun et al. (1992) used a correction of 1090 years for mollusc dates from the Ross Sea area, while Licht et al. (1996) used a reservoir correction of 1200 years for dates from the same area.

A number of investigations have assessed which correction of ${ }^{14} \mathrm{C}$ ages of Antarctic marine organisms has to be applied in order to establish a coherent radiocarbon chronology for Late Wisconsinan--Holocene glacial events. Circum-Antarctic studies generally show the average correction for reservoir age of marine mollusc shells to be $1100-1400{ }^{14} \mathrm{C} \mathrm{yr}$ (Y oshida \& Moriwaki 1979, Stuiver et al. 1981, Adamson \& Pickard 1986, Björck et al. 1991 a, Gordon \& Harkness 1992, Domack 1992, Berkman 1994, Berkman \& Forman 1996). Studies of pre-bomb seal, whale and penguin samples have yielded greater variability than the pre-bomb marine mollusc shells, ranging between $915 \pm 75$ and $1760 \pm 55 \mathrm{yr}$ (Curl 1980, Mabin 1985, Whitehouse et al. 1987, 1989, Baroni \& Orombelli 1991, Gordon \& Harkness 1992), suggesting that longevity and ecology of different species, as well as what tissue (flesh, bone, feathers, guano) is dated can significantly influence the correction factor needed (Mabin 1986, Baroni \& Orombelli 1991.) Berkman \& Forman (1996) suggested that reservoir corrections of $1300 \pm 100 \mathrm{yr}$ (molluscs), $1424 \pm 200 \mathrm{yr}$ (seals) and $1130 \pm 130 \mathrm{yr}$ (penguins) should be applied to Antarctic marine organisms.

In this paper we adopt $1300{ }^{14} \mathrm{C}$ yr as the best estimate for a circum-Antarctic correction for all ${ }^{14} \mathrm{C}$ dated marine organisms, for the sake of comparing glacial histories of the different areas. All ${ }^{14} \mathrm{C}$ ages given in the text have been corrected by that amount, no matter which reservoir correction or calibration was originally made by the authors cited as source of the data. All ages are in uncalibrated ${ }^{14} \mathrm{C}$ yr BP. At the same time we stress that there are still large uncertainties in the Antarctic marine reservoir effect.

\section{Deglaciation and Holocene glacial history in Antarctica}

The overall extent of ice cover in Antarctica during the LGM is not well known and some existing reconstructions are controversial. One maximum reconstruction suggests that the peripheral domes of the Antarctic Ice Sheet were $500-1000 \mathrm{~m}$ thicker than at present and that ice extended out to the continental shelf break around most of Antarctica (Denton 1979, Hughes et al. 1981, Clark \& Lingle 1979, Denton et al. 1991, Zhang 1992). Other reconstructions indicate a smaller ice extent. Mayewski (1975) maintained that the West Antarctic Ice Sheet was only slightly, if at all, larger than it is today. Data from East Antarctica have been interpreted as indicating that ice either did not extend to the shelf edge (Colhoun \& Adamson 1992a, Goodwin 1993) or 
that ice extended insignificantly farther out than today in some areas (Hayashi \& Yoshida 1994). The timing of the LGM around Antarctica is likewise poorly known, but most authors assume it to have coincided with the timing of lowest global sea levels around 20000-18000 yr BP. The LGM in the western Ross Sea area has been dated to $20000-17000 \mathrm{yr}$ BP (Stuiver et al. 1981, Anderson et al. 1992, Kellogget al. 1996, Licht et al. 1996). Hall (1997) has recently dated the LGM in Taylor Valley, southern Victoria Land, to $14600-12700 \mathrm{yr}$ BP. In East Antarctica, on the coast of Mac. Robertson Land and at Prydz Bay (Fig. 1) the LGM preceded $17000 \mathrm{yr}$ BP and $10700 \mathrm{yr} \mathrm{BP}$, respectively (Harris et al in press, Domack et al. 1991a).

\section{The Antarctic Peninsula region}

The Antarctic Peninsula ice sheet (Fig. 2) is a part of the marine-based West Antarctic Ice Sheet, where sea level is a major control on ice volume. Sugden \& Clapperton (1977) suggested, on the basis of bathymetric data showing glacial troughs incised into the submarine continental shelf, that during the LGM a number of ice caps formed on the South Shetland Islands, separated from the Antarctic Peninsula ice sheet by the deep Bransfield Strait. According to their reconstruction the main control for ice extension was sea level, and the presently $200 \mathrm{~m}$ deep submarine platforms

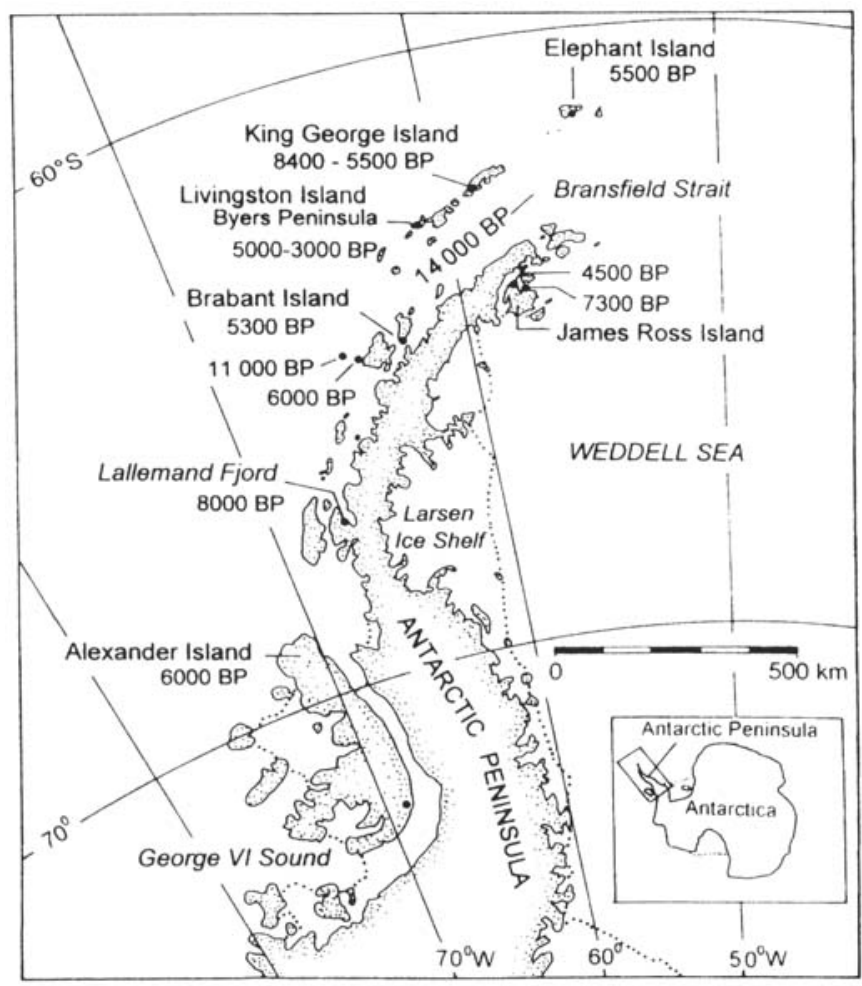

Fig. 2. The Antarctic Peninsula regions, with sites discussed in the text. Dots give approximate locations for ${ }^{14} \mathrm{C}$ dated samples giving minimum ages for the deglaciation. around the islands and along the Antarctic Peninsula roughly coincide with the ice extension. There is no evidence that the South Shetland Islands were overridden by ice from the Antarctic continent during the LGM (John 1972, Sugden \& Clapperton 1977), as suggested by Hughes (1975) and Hughes et al. (1981).

Evidence of more extensive ice cover than today exists all along the Antarctic Peninsula in the form of ice-abraded ridge crests at high altitudes, striated bedrock on presently ice-free islands, erratics and thin till deposits, as well as raised beach and marine deposits (John \& Sugden 1971, Sugden \& John 1973, Curl 1980, Clapperton \& Sugden 1982, 1988, Ingólfsson et al. 1992). The timing of the onset of deglaciation in the Antarctic Peninsula area is not known. Sugden \& John (1973) and Sugden \& Clapperton (1977) suggested that it was triggered by rising sea levels some time after $14000 \mathrm{yr}$ BP. Banfield \& Anderson (1995) found that the Bransfield basin was free of shelf ice as early as $14000 \mathrm{yr} \mathrm{BP}$, but recent investigations on the Antarctic Peninsula shelf (Pope \& Anderson 1992, Pudsey et al. 1994) indicate initial ice retreat from outer and middle shelf areas shortly before $11000 \mathrm{yr} \mathrm{BP}$.

Deglaciation of the inner shelf and the presently ice-free land areas in the Antarctic Peninsula region was considerably delayed after $11000 \mathrm{yr}$ BP. Some inner shelf areas were deglaciated as late as 8000 to 6000 yr BP (Clapperton \& Sugden 1982, Herron \& Anderson 1990, Pudsey et al. 1994, Shevenell et al. 1996). The oldest ${ }^{14} \mathrm{C}$ dates, on fossil molluscs from raised marine deposits give minimum ages for the deglaciation of northern Antarctic Peninsula coastal areas (Fig. 2) as $8400 \mathrm{yr}$ BP on the South Shetland Islands (Sugden \& John 1973) and 7300 yr BP on James Ross Island (Hortet al. (1997). At Alexander Island (Fig. 2) deglaciation occurred some time before $6000 \mathrm{yr}$ BP (Clapperton \& Sugden 1982). A number of studies on land suggest that once above the coastline, between $8400-6000 \mathrm{yr} \mathrm{BP}$, glaciers retreated and disintegrated slowly towards positions at or inside their present margins (Barsch \& Mäusbacher 1986, Mäusbacher et al. 1989, Mäusbacher 1991, Ingólfsson et al. 1992, Björck et al. 1993, 1996a, López-Martinez et al. 1996, Hjort et al. 1997). Data from Livingston Island (Fig. 2), in the South Shetlands, date the deglaciation of Byers Peninsula to 50003000 yr BP (Björck et al. 1996b). The deglaciation on King George Island was completed by $c .6000 \mathrm{yr}$ BP (MartinezMacchiavello et al. 1996).

There are indications of glacial readvance on King George Island(Sugden \& John 1973, Mäusbacher 1991) and expansion of the ice shelf in George VI Sound, east of Alexander Island (Sugden \& Clapperton 1981, Clapperton \& Sugden 1982), some time after 6000 yr BP. A glacial readvance also occurred on James Ross Island, culminating between 5000 and 4500 yr вр (Rabassa 1983, Hjort et al. 1997), and indications of a post-5300 yr BP glacial expansion have been described from Brabant Island (Hansom \& Flint 1989). Clapperton (1990) interpreted mid-Holocene glacier expansion in the Antarctic Peninsula region to reflect neoglacial cooling, 
whereas Ingólfsson et al. (1992) and Hjort et al. (1997) suggested that increases in precipitation might periodically have overcome increases in temperature in the generally cold climate, causing a cessation of mid-Holocene deglaciation or even glacial advance. However, recent nearshore marine data (Shevenell et al. 1996) may indicate a cooling background for these glacial readvances (Hjort et al. in press).

The present interglacial environment in the Antarctic Peninsula region dates back to $6000-5000 \mathrm{yr} \mathrm{BP}$, when lake sediments started to accumulate in ice-free basins, and moss banks began to grow (see Fenton 1982, Barsch \& Mäusbacher 1986, Mäusbacher et al. 1989, Mäusbacher 1991, Björck et al. 1991b, 1991d, 1993, 1996a, Yang \& Harwood 1997). Palaeoclimatic studies based on numerous stratigraphical parameters in lake sediments and moss-bank peats in the northern part of the region (Björck et al. 1991b, 1993, 1996a) indicate that the climate fluctuated from relatively mild and humid conditions at $5000 \mathrm{yr} \mathrm{BP}$ to more cold and arid conditions. Around $4000 \mathrm{yr}$ BP a gradual warming occurred, coupled with increasing humidity. These mild and humid conditions reached an optimum around $3000 \mathrm{yr} \mathrm{BP}$, whereafter a distinct climatic deterioration occurred, again with colder and drier conditions. Cold and arid climate then persisted until 1500 $1400 \mathrm{yr} \mathrm{BP}$, and thereafter the climate has been somewhat warmer and more humid, but still cold compared to the climatic optimum. The climatic pattern for the last 5000 years is quite similar in the South Shetland Islands, in the maritime climate west of the peninsula and James Ross Island, and in the colder and drier polar climate in the western Weddell Sea. Björck et al. (1996a) suggested this might indicate that the primary factor controlling the climatic variations is the strength of the high-pressure atmosphere cell over the Antarctic ice sheet.

A number of investigations indicate that glaciers have oscillated and expanded somewhat in the Antarctic Peninsula region during the past 2500 years (John \& Sugden 1971, Sugden \& John 1973, Zale \& Karlén 1989, Clapperton 1990, López-Martínez et al. 1996). In the South Shetland Islands, Curl (1980), Birkenmajer (1981), Clapperton \& Sugden (1988) and Björck et al. (1996b) found evidence for glacial expansions in the form of readvance moraines on raised beaches, which they suggested coincided with the Little Ice Age glacial expansion in the Northern Hemisphere. Radiocarbon dating on whalebones found on some raised beaches give recent ages when a sea correction of $1300 \mathrm{yr}$ is applied, but lichenometric dating, using Rhizocarpon geographicum thalli, dates the advances to $1240 \mathrm{AD}$ (Birkenmajer 1981), $1720 \mathrm{AD}$ (Curl 1980) and 1780-1822 $\mathrm{AD}$ (Birkenmajer 1981). Limiting dates of $1837 \mathrm{AD}$ and $1880 \mathrm{AD}$ were derived from lichenometry for two moraines in the South Orkney Islands (Lindsay 1973). A whalebone found on top of a moraine-ridge on Livingston Island dates a glacial advance there to after $1690 \mathrm{AD}$ (Björck et al. 1996b).

A marine record from near-shore glaciomarine sediments in Lallemand Fjord (Fig. 2) indicates a pattern broadly similar to the record on land from the Antarctic Peninsula region (Shevenell et al. 1996). There, deglaciation of the inner shelf occurred somewhat before $8000 \mathrm{yr} \mathrm{BP}$, and was followed by a period of open marine conditions with variable extent of sea ice between 8000 and $2700 \mathrm{yr} \mathrm{BP}$. However, the data indicate a cooling between $6000 \mathrm{yr} \mathrm{BP}$ and $5000 \mathrm{yr} \mathrm{BP}$, which might coincide with the mid-Holocene glacial readvances mentioned above. A climatic optimum, reflected by high productivity in the fjord, was recognized between 4200 and $2700 \mathrm{yr}$ BP. After $2700 \mathrm{yr}$ BP, a decrease in productivity and diatom abundance reflects more extensive and seasonally persistent sea ice. After $400 \mathrm{yr}$ BP, ice shelf advance into the fjord was documented, correlating with the Little Ice Age (Shevenell et al. 1996, Domack et al. 1995).

A broad synthesis of the glacial history and related Holocene environmental development in the Antarctic Peninsula region is shown in Fig. 3.

\section{East Antarctica}

The extent of ice during the LGM in East Antarctica is not well known and partly controversial. A maximum

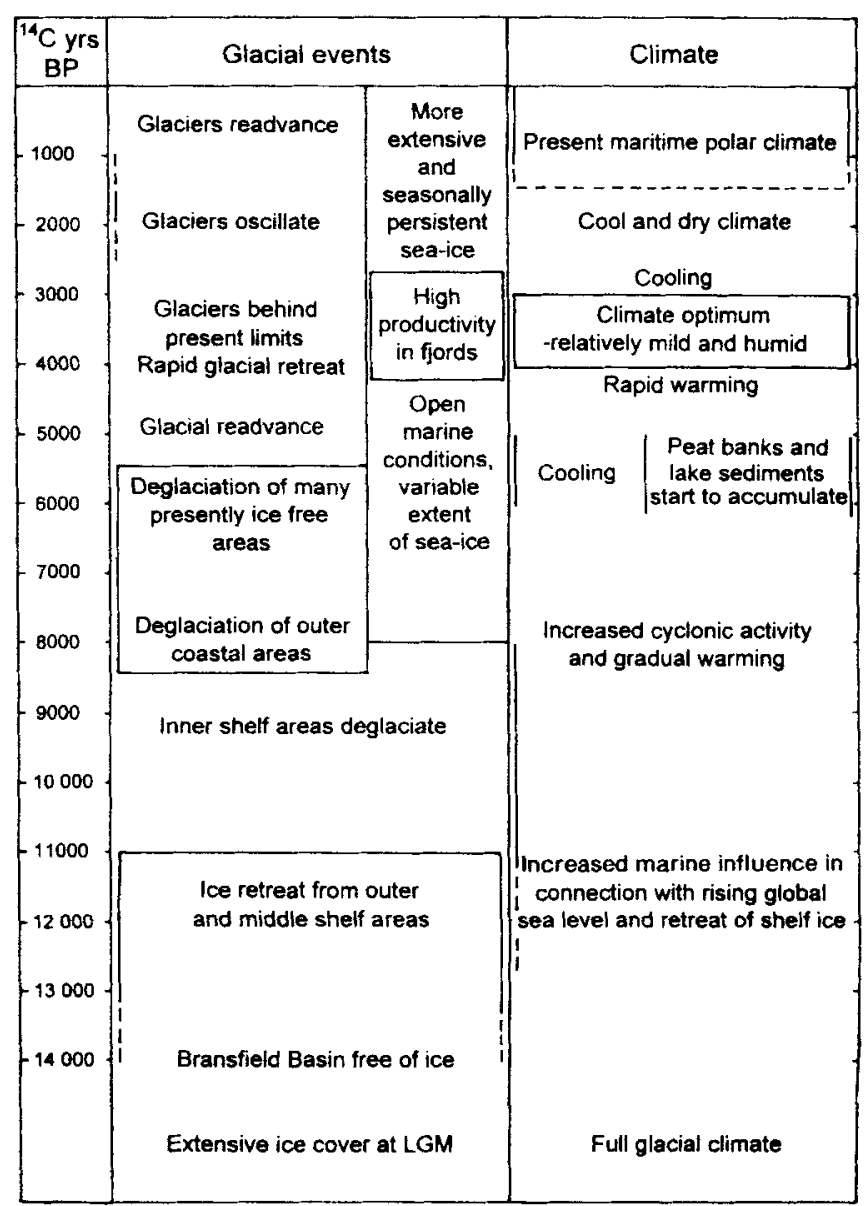

Fig. 3. Broad synthesis of the Antarctic Peninsula glacial development and associated environmental changes since the LGM. 
reconstruction extends ice to the shelf break (Denton 1979 , Hughes et al. 1981) while a minimalist view suggests only modest glacial oscillations and that some coastal oases remained ice free (Omoto 1977, Hayashi \& Yoshida 1994, Adamson et al. 1997). Other data from East Antarctica suggest that ice extended off the present coast, but not all the way to the shelf edge(Colhoun \& Adamson 1992a, Fitzsimons \& Domack 1993, Goodwin 1993). The ice-free areas in East Antarctica, discussed below, are the Vestfjella and Heimefrontfjella nunatak ranges in western Dronning Maud Land, the Schirmacher and Untersee oases, Lützow-Holm Bay, Larsemann Hills and Vestfold Hills in Prydz Bay, Bunger Hills and Windmill Islands (Fig. 1).

Sedimentological data and ${ }^{14} \mathrm{C}$ dates from the Weddell Sea suggest that a grounded ice sheet extended to the shelf break off western Dronning Maud Land at 20000 yr BP (Elverhøi 1981). Jonsson (1988) used observations of glacial striae to reconstruct ice thickness at the LGM in northern Vestfjella, and concluded that the ice there had been $360 \mathrm{~m}$ thicker than today, but that the highest nunataks had been ice-free. Lintinen \& Nenonen (1997) concluded that during the LGM the ice sheet was at least $700 \mathrm{~m}$ thicker in northern Vestfjella than today, while in Heimefrontfjella it was less than $200 \mathrm{~m}$ thicker. ${ }^{14} \mathrm{C}$ dates of stomach oil deposits from nesting sites of snow petrels (Pagodroma nivea) give $7400 \mathrm{yr}$ BP as the minimum age for deglaciation of the southern Vestfjella nunataks and the lower altitudes of Heimefrontfjella and record continuous avian occupation since then.

Schirmacher Oasis (Fig. I) is an ice-free area located c. $100 \mathrm{~km}$ south of the Lazarev Sea. It covers an area of $34 \mathrm{~km}^{2}$. Another $100 \mathrm{~km}$ to the south, Untersee Oasis (Fig. 1) forms the eastern rim of the unglaciated Wohlthat Massif, surrounding Lake Untersee.

At least four generations of moraines have been differentiated in the Untersee Oasis (Stackebrand 1995). They were interpreted as glaciation and deglaciation stages, representing a succession from a total submergence by the inland ice towards the present ice-free setting. The last total ice coverage probably predates the LGM (Hiller et al. 1988). This is indicated by Late Wisconsinan ${ }^{14} \mathrm{C}$ ages on snow petrel stomach oil deposits from high-altitude locations in the Untersee Oasis. Lake Untersee (169 m deep and $11.4 \mathrm{~km}^{2}$ in area) perhaps existed during the Late Pleistocene, but at least since earliest Holocene time (M. Schwab, personal communication 1998).

The last glacial submergence of Schirmacher Oasis is reflected in a sparse coverage of morainic material, fractured rocks, striated surfaces and roches moutonnées at many places in the oasis (Richter \& Bormann 1995). ${ }^{14} \mathrm{C}$ dating of lake sediments suggests that deglaciation of Schirmacher Oases started before 3500 yr BP (M. Schwab, personal communication 1998). Hence, deglaciation here may have occurred significantly later than in Untersee Oasis to the south (see above), and also later that on the Lazarev Sea shelf to the north, where it was under way by $9500 \mathrm{yr}$ BP (Gingele et al. 1997).

No indications are known from Untersee or Schirmacher oases for significant Holocene readvances of ice margins. However, grain-size distribution and radiocarbon ages of sediments on the Lazarev Sea shelf could indicate that ice tongues to the east may have readvanced some time between 8000 and 2000 yr BP (Gingele et al. 1997).

The only available information on the Holocene climate development of the region comes from Lake Untersee. Today it has a perennial ice cover, up to $5 \mathrm{~m}$ thick, but its sediment composition indicates that during the early Holocene the ice cover was only semi-permanent (M. Schwab, personal communication 1998). That might have been due to a warmer climate.

Ice-free areas fringing Lützow-Holm Bay (Fig. 1) occur on a number of islands and headlands, the largest one being $61 \mathrm{~km}^{2}$. Signs of glaciation occur as discontinuous glacial drift and erratics, striated bedrock surfaces and streamlined glacial bedforms, and extensive raised beaches (Yoshikawa \& Toya 1957, Hirakawa et al. 1984, Yoshida 1983, Igarahi et al. 1995, Maemoku et al. 1997, Sawagaki \& Hirakawa 1997). Omoto (1977) and Hayashi \& Yoshida (1994) concluded that ice retreat from the Lützow-Holm Bay area occurred before $30000 \mathrm{yr} \mathrm{BP}$, and that it had not been ice-covered during the LGM. Igarashi et al. (1995) concluded that the last major deglaciation in the area dated back to the last interglacial, on the basis of the occurrence of old (42000-33000 yr BP) fossil shells in raised beach deposits. Maemoku et al. (1997) also described old (46 000-32000 yr BP) fossil shells from Lützow-Holm Bay in undisturbed raised beach deposits, and interpreted these data to indicate the area had not been overridden by glaciers during the LGM. The location of the ice-margin during the LGM is unknown (Igarashiet al. 1995, Maemoku et al. 1997). Raised beaches of Holocene age, 7000 to 2000 yr BP (Igarashi et al. 1995) do, however, occur. The Holocene marine limit is at $25 \mathrm{~m}$ a.s.l., indicating considerable regional isostatic response to decreased ice volume. Maemoku et al. (1997) suggested the East Antarctic ice sheet might have covered the southern part of LützowHolm Bay during the LGM. Nothing is known about the Holocene climate development in this area.

The Amery Ice Shelf (Fig. 1), the largest in East Antarctica, has been present throughout the Holocene since retreat from the LGM terminal moraines at mid-shelf in Prydz. Bay (Harris \& O'Brien, personal communication 1997). It has been suggested that the small $\left(50 \mathrm{~km}^{2}\right)$ oasis of Larsemann Hills in Prydz Bay (Fig. 1) was either wholly or partly ice free during the LGM (Burgess et al. 1994, 1997) or completely covered by $200-500 \mathrm{~m}$ thick continental ice (Gillieson 1991). Erratic boulders are scattered throughout the Hills, but till deposits, moraine ridges and glacial striae occur only sparsely (Burgess et al. 1994). A number of sediment cores has been retrieved from lakes in the Larsemann Hills. There are serious problems 
with radiocarbon dating of the sediments, expressed as reversed stratigraphical age successions (Burgess et al. 1994). While most dated samples give mid-late Holocene ages, a single date gave $9400 \mathrm{yr} \mathrm{BP}$ and another $25000 \mathrm{yr} \mathrm{BP}$.

There is no evidence of postglacial raised beaches in the Larsemann Hills, in contrast to extensively developed beaches in the Vestfold and Bunger Hills (Fig. 1). Their absence is puzzling, both if the oasis was ice free during the LGM or if it was gradually deglaciated in Holocene times.

During the LGM the whole $400 \mathrm{~km}^{2}$ of the Vestfold Hills oasis in Prydz Bay (Fig. 4) was covered by ice (Adamson \& Pickard 1983,1986 ). Evidence of glacial overriding include glacial striae, erratics, till deposits and moraine ridges, as well as raised beaches at altitudes below $10 \mathrm{~m}$ a.s.l. (Pickard 1985, Zhang 1992). The orientation of glacial striae is uniform, showing ice movement towards WNW across the oasis at a time of complete ice coverage (Adamson \& Pickard 1983, 1986). According to Domack et al. (199la, 1991b), open marine conditions existed on the shelf, some $30 \mathrm{~km}$ off Vestfold Hills, at $10700 \mathrm{yr}$ BP. The last deglaciation of Vestfold Hills has been determined by ${ }^{14} \mathrm{C}$ dates on molluscs from raised marine deposits and moraines, on marine algal sediments from numerous lake basins, and on fossil mosses (Adamson \& Pickard 1983,1986, Pickard 1985, Pickard \& Seppelt 1984, Pickard et al. 1986, Bronge 1992). A prominent feature of the Vestfold Hills is its numerous lakes. There are about 300 lakes, from freshwater to saline and hypersaline. Many were formerly marine inlets and became isolated by isostatic uplift following the glacial retreat. The oldest ${ }^{19} \mathrm{C}$ dates, giving minimum ages for the initial deglaciation and the incursion of marine water onto coastal areas, as well as for the initiation of aquatic moss growth, are between $8600-8400$ yr BP (Pickard \& Seppelt 1984, Fitzsimons \& Domack 1993, Roberts \& McMinn in press). According to Adamson \& Pickard (1986) and Pickard et al. (1986), ice retreat thereafter was slow or stepwise, averaging 1-2 $\mathrm{m} \mathrm{yr}^{-1}$, with $20 \%$ of the land area exposed by 8000 yr BP, $50 \%$ by $5000 \mathrm{yr} \mathrm{BP}$, and the ice margin reaching its present position in the last 1000 yrs. Fitzsimons \& Domack (1993) and Fitzsimons $\&$ Colhoun (1995) maintain that the margin of the Sørsdal Glacier (Fig. 4), in the southern part of the Vestfold Hills was at or south of its present position by $8600 \mathrm{yr}$ BP and has been relatively stable since then. The data of Fitzsimons \& Domack (1993) show that deglaciation of at least part of the Vestfold Hills occurred earlier than previously thought.

Domack et al. (1991b) found evidence on the shelf for a middle Holocene readvance of floating ice tongues some time within the interval $7300-3800 \mathrm{yr}$ BP. There is no dated evidence for this from the Vestfold Hills, but Adamson \& Pickard (1986) suggested that moraine ridges on Broad Peninsula(Fig.4) may have formed during a middle Holocene glacial advance. A late Holocene ice advance, called the Chelnok glaciation, is poorly dated but probably occurred some time between 2000 and $1000 \mathrm{yr}$ BP (Pickard et al. 1984,
Adamson \& Pickard 1986, Zhang 1992). Fitzsimons \& Colhoun (1995) found evidence for minor $(\leq 500 \mathrm{~m})$ late Holocene (post $700 \mathrm{yr} \mathrm{BP}$ ) ice marginal fluctuations in the form of a discontinuous series of ice-cored moraine ridges. These may correlate with the Little Ice Age.

There is no detailed record for the Holocene climatic development in Vestfold Hills. Pickard et al. $(1984,1986)$ concluded that the "post-glacial" climate of Vestfold Hills had been very stable and similar to today's. Zhang (1992), however, on the basis of marine fossil assemblages and geomorphological criteria, proposed that a climatic optimum had occurred there sometime between 6200 and $3700 \mathrm{yr} \mathrm{BP}$. In the geomorphological record, Pickard (1982) found evidence that the prevailing wind direction had been stable for the past 4000 years. The climatic implications of the Chelnok advance are unclear (Pickard et al. 1984, Adamson \& Pickard 1986).

Björck et al. (1996a) re-interpreted the lake sediment data of Pickard et al.(1986) in terms of palaeoclimate development of the Vestfold Hills. They suggested that the deglaciation of the Watts Lake area (Fig. 4) prior to $4700 \mathrm{yr}$ BP occurred in an arid and cold environment (low lake levels, high salinity), followed by a relatively warm and humid climate between 4700 and $3000 \mathrm{yr}$ BP which caused intense melting of stagnant ice in the vicinity of the lakes. Massive input of fresh water into the basins caused salinity to fall and lake levels to rise.

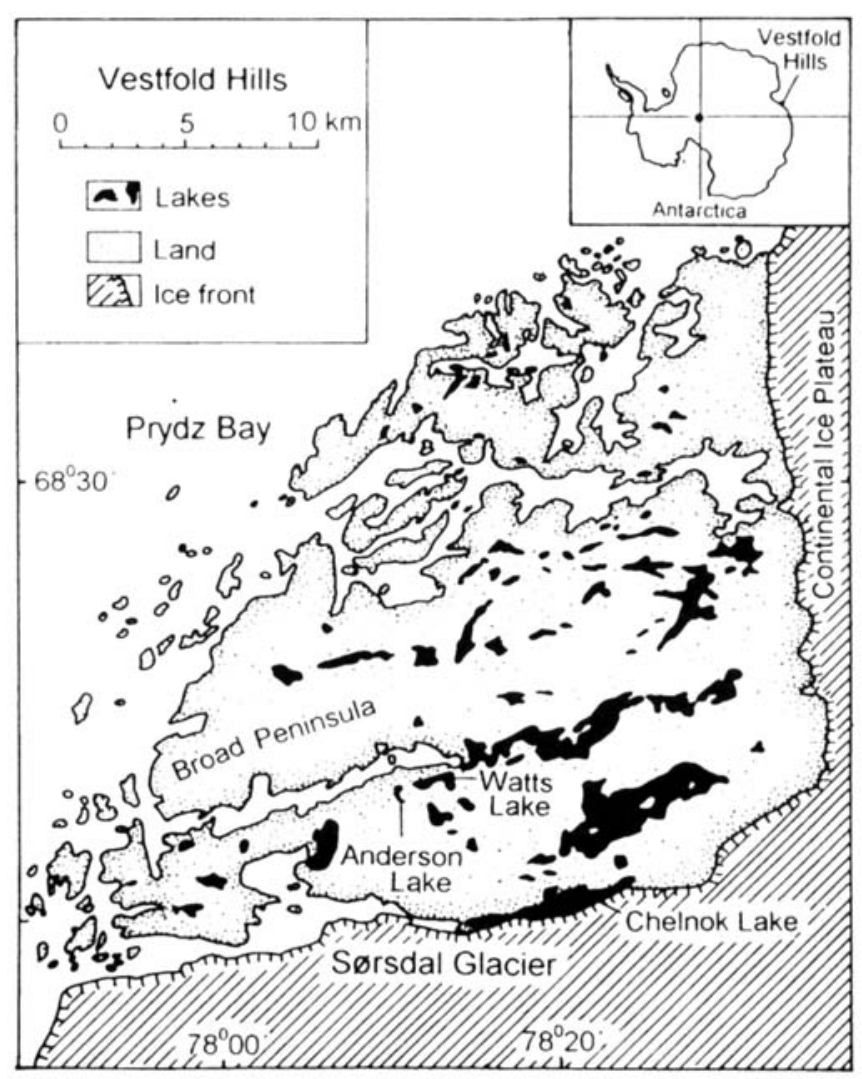

Fig. 4. The Vestfold Hills oasis in Prydz Bay, East Antarctica. 
After $3000 \mathrm{yr}$ BP the climate again turned arid and cold, with decreased fresh water input and lowered lake levels. Björck et al. (1996a) thus inferred a late Holocene (4700-3000 yr BP) climate optimum in the Vestfold Hills data.

Roberts \& McMinn (1996, in press) used transfer functions for the reconstruction of past lakewater salinity from fossil diatom assemblages. They found that since $5200 \mathrm{yr} \mathrm{BP}$, Anderson Lake (Fig. 4) in the Vestfold Hills had undergone cycles of varying salinity. The data show a long period with relatively low salinity, possibly indicating warmer and wetter conditions in the time interval c. $4200-2200 \mathrm{yr} \mathrm{BP}$, if a constant sedimentation rate of $0.007 \mathrm{~cm} \mathrm{y}^{-1}$ since $5200 \mathrm{yr} \mathrm{BP}$ is assumed. The glacial history of Vestfold Hills since the LGM is summarized in Fig. 5.

Bunger Hills (Fig. 6) form the most extensive oasis of deglaciated hills and marine inlets in East Antarctica, with a total size of $952 \mathrm{~km}^{2}$, of which $482 \mathrm{~km}^{2}$ are land (Wisniewski 1983). There are signs of extensive glaciation in the form of discontinuous but locally thick glacial drift deposits, striated bedrock surfaces, roches moutonnées and erratics, as well as extensive raised beaches. Colhoun \& Adamson (1992a) and Augustinus et al. (1997) suggested that there is evidence that at some stage in the past the Antarctic ice sheet completely submerged most of the oasis, and that ice flow from south-east to north-west was independent of the local topography. Augustinus et al.(1997) proposed that this extensive glaciation may have predated the LGM. Limited glacial erosion, thick glacial deposits in the north-western part of the hills and the relatively low altitude of the postglacial marine limit (9-7 m a.s.l.) suggested to Colhoun \& Adamson (1992a) and Colhoun (1997) that the LGM ice sheet was not very thick and consequently did not extend far onto the continental shelf. Melles et al. (1997) found till in 18 sediment cores retrieved from different basins within the oasis. They concluded that probably the whole oasis was buried by glaciers during the LGM.

${ }^{14} \mathrm{C}$ dates on total organic carbon from lacustrine and marine sediments indicate that the initial deglaciation of the southern part of the Bunger Hills oasis dates back to between $10000-8000$ yr BP (Bolshiyanov et al. 1990, 1991, Melles et al. 1994, Melles et al. 1997), and radiocarbon dates of stomach oil deposits at nest sites of snow petrels show occupation as early as $9500 \mathrm{yr} \mathbf{B P}$ (Bolshiyanov et al. 1991. Verkulich \& Hiller 1994). The glacial retreat was partly controlled by the rise of sea level, which caused a relatively rapid collapse of the ice sheet margin (Colhoun \& Adamson 1992a, Verkulich \& Melles 1992). Melles et al. (1997) conclude that the first phase of deglaciation was also associated with climatic warming, indicated by high diatom concentrations in the sediments and a large meltwater input to the basins. By $7700 \mathrm{yr}$ BP the sea had flooded all major inlets in Bunger Hills (Colhoun \& Adamson 1991, Melles et al. 1997). The breeding colonies of snow petrels expanded continually, following ice retreat and the down-wasting of dead ice (Verkulich \& Hiller 1994), with the most intense

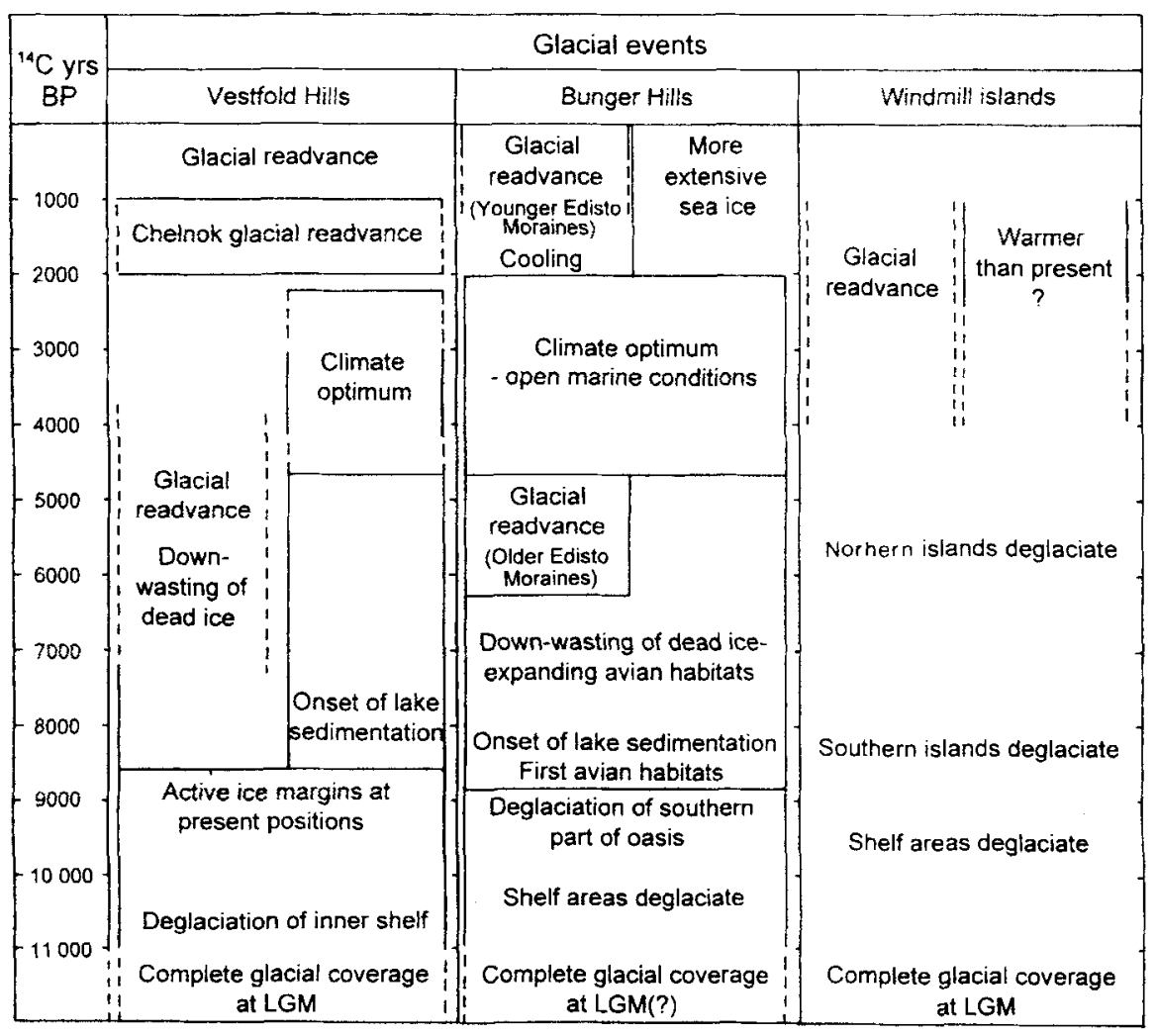

Fig. 5. Summary of the most complete East Antarctic records on glacial and climatic development since the LGM. 
phases of colonization between $6700 \mathrm{yr}$ BP and $4700 \mathrm{yr}$ BP. Before $5600 \mathrm{yr} \mathrm{BP}$, when the sea stood at the marine limit at 9-7 m, glaciers were at or behind their present margins (Colhoun \& Adamson 1992a, Colhoun \& Adamson 1992b). Melles et al. (1997) dated initiation of lacustrine sedimentation in the northern part of Bunger Hills to $6000 \mathrm{yr} \mathrm{BP}$.

Evidence for the mid-late Holocene glacial and climatic evolution of Bunger Hills is, however, somewhat controversial. Bolshiyanov et al. (1991) suggested that the area was reglaciated several times during the Holocene, causing damming of tributary valleys with periodic lake sediment deposition. They based their conclusions on lake sediment thickness, as well as on fluctuations in the growth rate of aquatic mosses and algae, and on changing salinity conditions as reflected by diatom assemblages and the geochemistry of lake sediments. Verkulich \& Hiller (1994) found no evidence of any major Holocene glacial advance in the Bunger Hills and Colhoun \& Adamson (1992a), Fitzsimons \& Colhoun (1995) and Fitzsimons (1997) concluded that ice margins at the southern boundary of Bunger Hills had been fairly stable since the last deglaciation. At the western margin, however, glacier expansions of a few hundred metres resulted in the formation of the older Edisto moraines, post-dating $6200 \mathrm{yr} \mathrm{BP}$ (Colhoun \& Adamson 1992a).

Verkulich \& Melles (1992) and Melles et al. (1997) studied sediment cores from freshwater lakes and from marine basins in the Bunger Hills. Melles et al. (1997) reported high and stepwise increasing biogenic production between 4700 and $2000 \mathrm{yr} \mathrm{BP}$, taken to indicate increased temperatures and correlated with the Antarctic Peninsula climate optimum at about the same time. Melles et al. (1997) also concluded that the glacial advance forming the older Edisto moraines predated the $4700 \mathrm{yr}$ BP warming. This constrains the Edisto advance to some time between $6200-4700 \mathrm{yr} \mathrm{BP}$, which is coincident with the cooling and glacial readvance in the Antarctic Peninsula area (see above). Colhoun \& Adamson (1992a, 1992b) agreed with Rozycki's (1961) interpretation of beach morphology, suggesting that wave action may have been more important in the mid-Holocene, and that the extent and duration of sea ice has increased in the late Holocene.

Melles et al. (1997) found indications of climatic deterioration after $2000 \mathrm{yr} \mathrm{BP}$ and of subsequent warming to an intermediate level until the present. Colhoun \& Adamson (1992a) described a glacial advance during the last few centuries, leading to the formation of the younger Edisto moraines. Melles et al. (1997) concluded that the younger Edisto moraines postdate $1100 \mathrm{yr} \mathrm{BP}$. Marine shell fragments collected from the moraines were dated to $200 \mathrm{yr} B P$ (Colhoun \& Adamson 1992a), suggesting a Little Ice Age glacial event. A summary of the Bunger Hills data on deglaciation and associated environmental changes is given in Fig. 5.

Windmill Islands (Fig. 1) are a group of low islands and peninsulas, forming a major oasis on Budd Coast in East Antarctica. Evidence of an extensive late Pleistocene ice

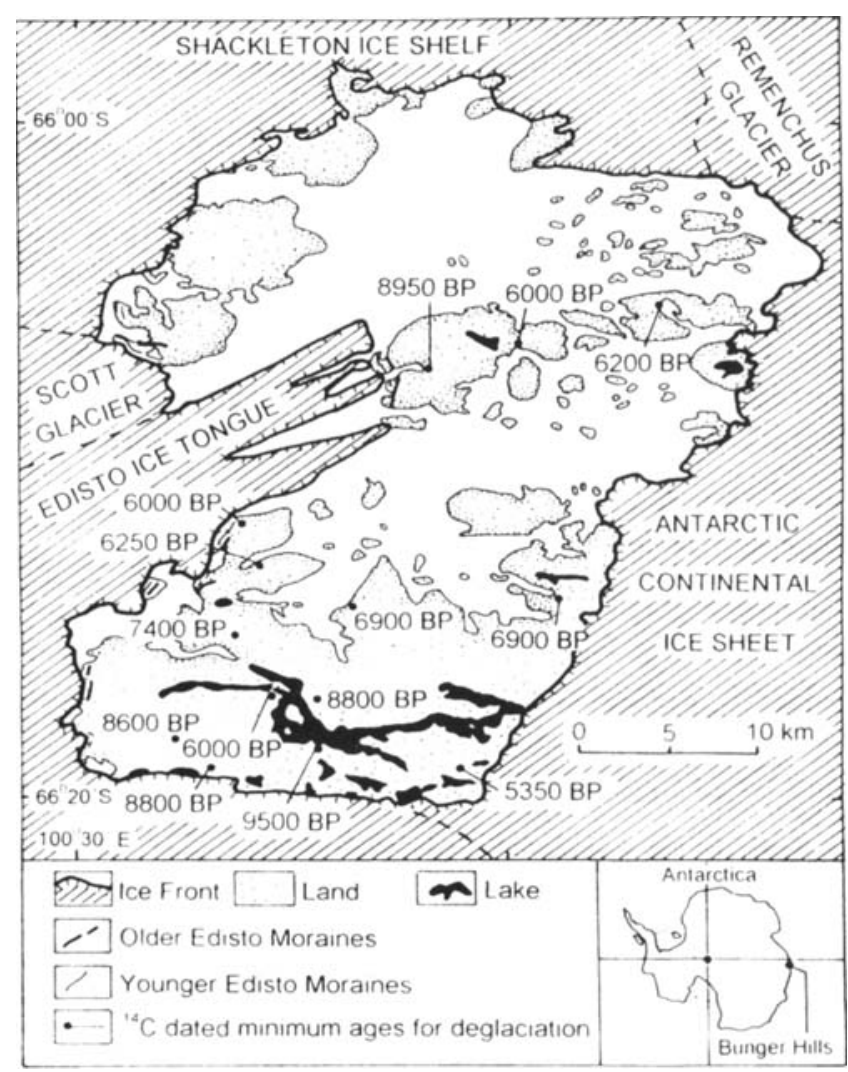

Fig. 6. The icebound Bunger Hills oasis, East Antarctica. Dots give locations of some selected sites where ${ }^{14} \mathrm{C}$ dated samples give minimum ages for deglaciation (modified from Colhoun \& Adamson 1992a and Verkulich \& Hiller 1994).

cover are glacial polishing and striae on the gneiss bedrock, roches moutonnees and erratics, as well as raised beaches at altitudes below $32 \mathrm{~m}$ a.s.l. (Goodwin 1993). A shallow veneer of unconsolidated sediments occurs on the islands. Cameron et al. (1959) interpreted this as reworked till, but Goodwin (1993) found subglacially deposited fine sediments almost totally lacking. He argued that the best indicator for glacial overriding during the LGM were the raised beaches, bearing witness to isostatic rebound in connection with deglaciation. Goodwin (1993) calculated that the Late Pleistocene-early Holocene ice thickness over the Windmill Islands and the inner shelf had been $<200 \mathrm{~m}$ and $<400 \mathrm{~m}$, respectively, and that ice had extended $8-15 \mathrm{~km}$ off the present coast.

Radiocarbon dating on bulk samples from basal lake sediments provides minimum estimates for the deglaciation of the Windmill Islands (Goodwin 1993). These indicate that the southern part of the islands were deglaciated before 8000 yr BP (Fig. 5), while the northern islands were only deglaciated some time before $5500 \mathrm{yr}$ BP. Very little is known about the post-glacial Holocene climate development at Windmill Islands. Goodwin (1993) interpreted the onset of algal growth in the lakes to indicate warmer conditions than at present between 2000 and $1000 \mathrm{yr}$ BP. He also found 
indications of higher lake levels during that period.

There is evidence for a readvance of the Law Dome ice sheet margin onto part of the Windmill Islands some time between 4000 and $1000 \mathrm{yr} \mathrm{BP}$ (Goodwin 1996). The overriding advance of the ice margin incorporated frozen coastal sediments from raised beach, lacustrine and proglacial environments together with slabs of marine ice from a palaeo-ice shelf, during the marginal transition from fringing ice shelf to grounded ice sheet. Goodwin (1996) attributed the readvance to a positive mass balance on the Law Dome caused by high precipitation rates during the Holocene.

\section{Summary of the East Antarctic data}

There is a broad pattern in the glacial histories from East Antarctica (Fig. 7). All studies infer relatively moderate ice thickness during the LGM, with ice extending off the present

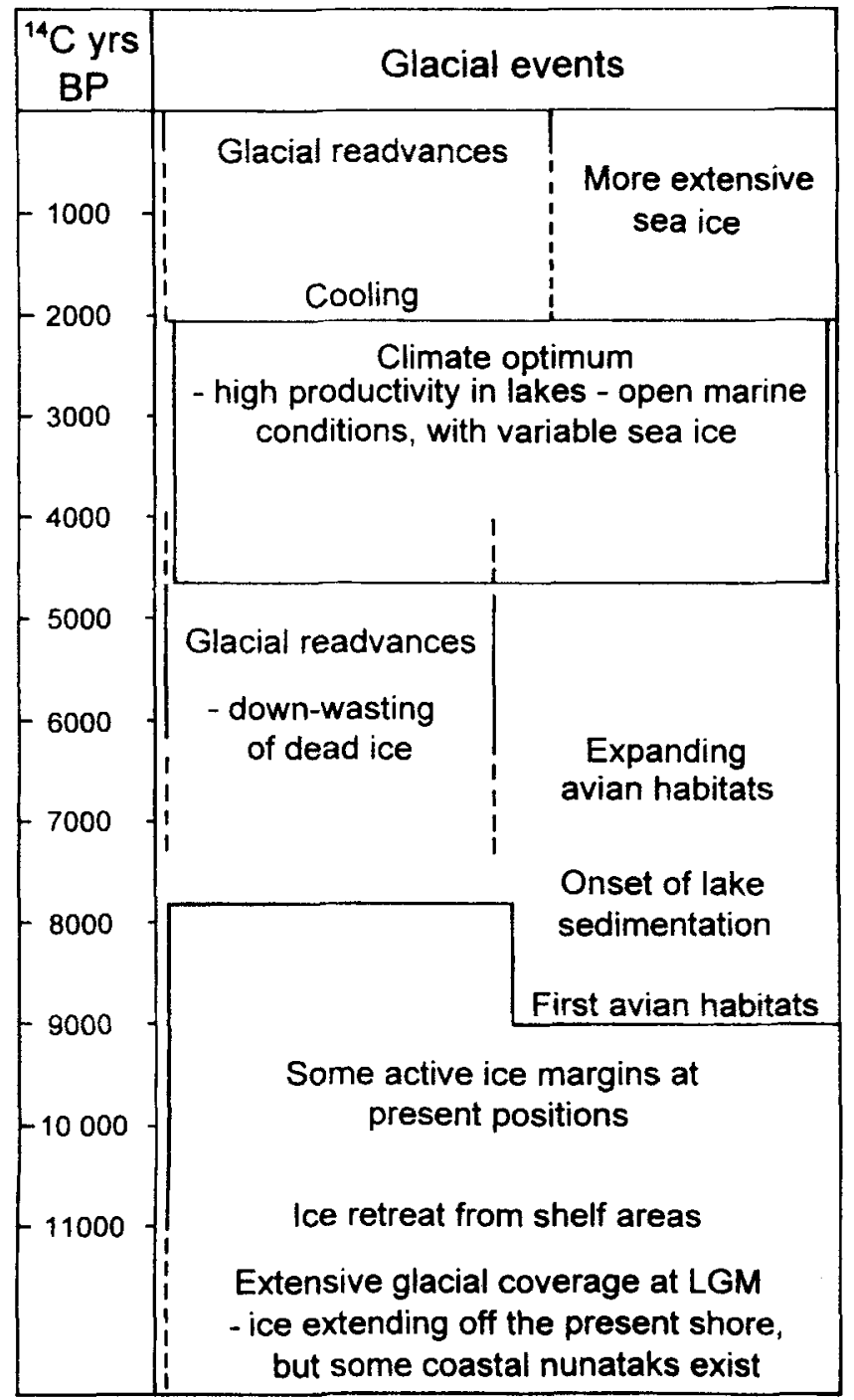

Fig. 7. Broad synthesis for the glacial and climatic development in East Antarctica since the LGM. shore, but not very far onto the shelf. Some areas may have remained wholly or partly ice free throughout the LGM (Schirmacher and Untersee oases, Larsemann Hills, LützowHolm Bay). Ice retreat from the shelf areas was under way by $11000-10000 \mathrm{yr}$ BP. The oldest deglaciation dates show marine and lacustrine environments, as well as avian habitats, developing in coastal areas between $10000-8000 \mathrm{yr}$ BP. The deglaciation history of Vestfold Hills is controversial. One reconstruction specifies it as successive and slow and mainly post-dating $8000 \mathrm{yr} \mathrm{BP}$. In the other reconstruction, deglaciation was more or less complete by $8600 \mathrm{yr}$ BP. There are indications from Vestfold Hills of a mid-Holocene glacial advance. The combined data from Bunger Hills show an early initial deglaciation phase, and retreat of the continental ice sheet margin to its present position by $10000 \mathrm{yr}$ BP. The retreat was coupled with collapse of ice over the marine inlets while the land was still depressed below present sea level around the Pleistocene-Holocene transition. Most of the downwasting of dead ice may have occurred successively after $8800 \mathrm{yr}$ BP. There are indications of a mid-Holocene glacial readvance: expansion of the Edisto Glacier occurred after $6200 \mathrm{yr}$ BP and before $4700 \mathrm{yr}$ BP. The Windmill Islands were successively deglaciated between 8000 and $5500 \mathrm{yr}$ BP. There are indications from both Vestfold Hills and Bunger Hills of a climate warmer and wetter than the present in the interval c. $4700-2000 \mathrm{yr} \mathrm{BP}$, and the Windmill Islands record may tentatively be interpreted as indicating the same for the $4000-1000$ yr BP interval. The East Antarctic data also show minor fluctuations of the ice margins over the past few hundred years (Goodwin in press), possibly correlative with the Little Ice Age advances in the Northern Hemisphere.

\section{The Ross Sea area and coastal Victoria Land}

The Ross ice drainage system comprises about $25 \%$ of the surface of the Antarctic Ice Sheet. Since the dawn of geological research in Antarctica there has been a discussion about the fluctuations of ice in the Ross Sea and Victoria Land (Fig. 8) in space and time (reviews in Stuiver et al. 1981 and Denton et al. 1989, 1991). Reconstructions of the LGM ice flowlines for the drainage of the East and West Antarctic ice sheets to the Ross Sea are conflicting (Drewry 1979, Denton et al. 1989, Clapperton \& Sugden 1990, Kellogg et al. 1996), but most studies suggest that the Ross Sea embayment was largely filled by a low surface profile, marine based ice sheet. Glacial drift deposits (Ross Sea drift), containing kenyte erratics from Ross Island, show that during the LGM the West Antarctic ice sheet thickened and grounded in the Ross Sea and McMurdo Sound, pushing lobes of ice onto coastal southern Victoria Land and damming the Dry Valleys (Stuiver et al. 1981, Denton et al. 1989, 1991). Farther north along the Victoria Land coast, major outlet glaciers, in e.g., Terra Nova Bay, drained the East Antarctic ice sheet and coalesced with the marine based ice in the Ross Sea (Denton et al. 1989, Orombelli et al. 1991). Although reconstructions of ice 


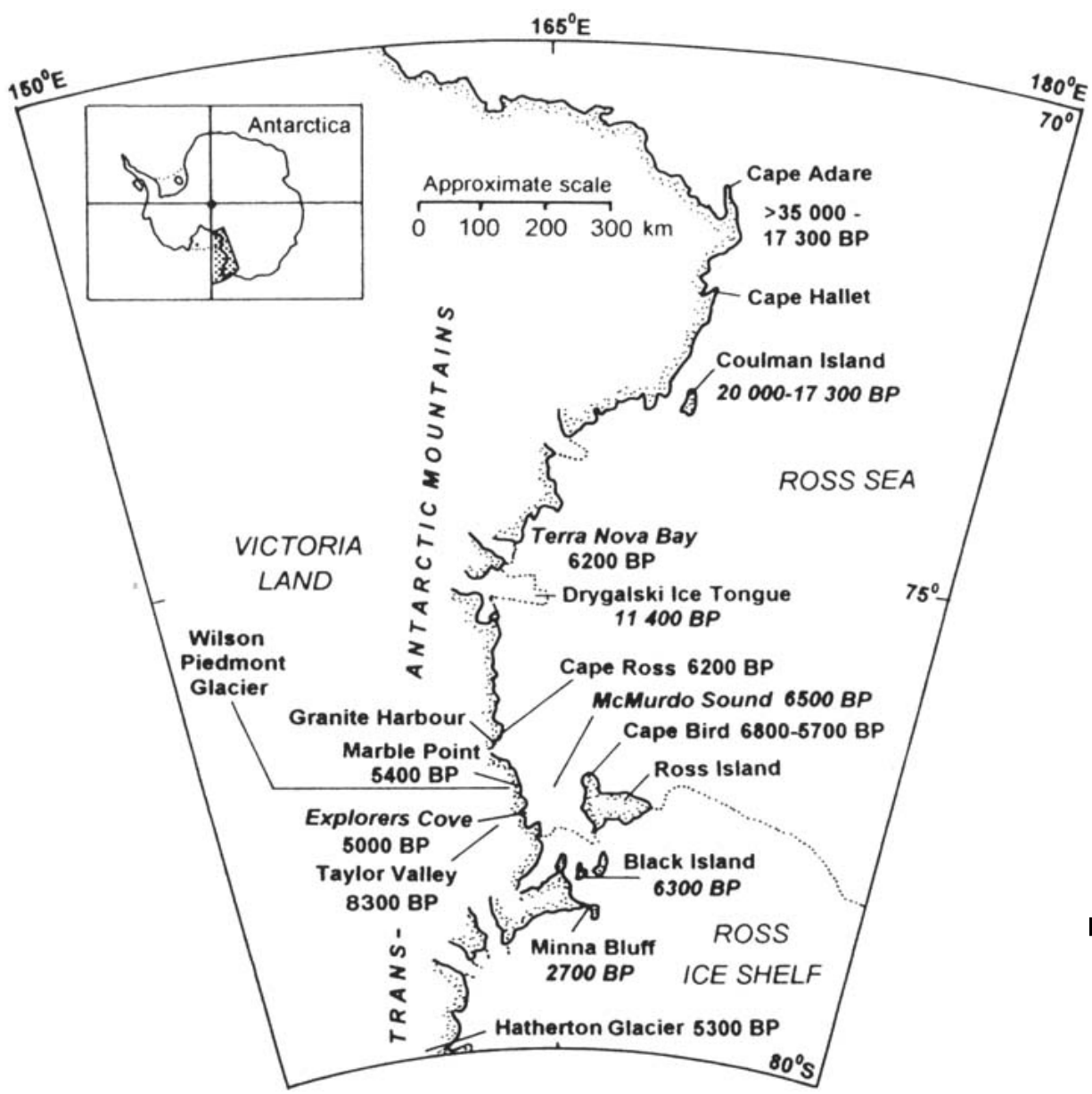

Fig. 8. The Ross Sea-Victoria Land region, with minimum ages for deglaciation. Radiocarbon ages in italic refer to grounding line recession.

extent in the Ross Sea during the LGM agree that ice was considerably expanded compared to the present (see Drewry 1979, Stuiver et al. 1981, Anderson et al. 1984, Denton et al. 1989, 1991, Clapperton \& Sugden 1990, Orombelli et al. 1991, Kellogg et al. 1996, Licht et al. 1996), there remains uncertainty about the maximum position of the grounded ice. Licht et al. (1996) recognized tills in the western Ross Sea, but only in areas south of Coulman Island. Kellogg et al. (1996) suggested that grounded LGM ice extended to the shelf break off Cape Adare, while Denton et al. (1989), Anderson et al. (1992), Baroni \& Orombelli (1994a), Shipp \& Anderson (1994) and Licht et al. (1996) placed the LGM-grounding line along the northern Victoria Land coast in the vicinity of Coulman Island, between $74^{\circ} \mathrm{S}$ and $73^{\circ} \mathrm{S}$. Anderson et al. (1992) dated the grounding line there to $17300 \mathrm{yr}$ BP whereas Licht et al. (1996) dated it to c. $20000 \mathrm{yr}$ BP. Penguin rookeries at Cape Adare and Cape Hallet were probably occupied between $>35000$ and 17300 yr BP (Baroni \& Orombelli 1994a). Since these can exist only where there is access to open water in summer, they show that the coastal north-western Ross Sea was free of glacial ice during the LGM.

The terrestrial data on the timing and pattern of deglaciation derive from studies of lacustrine sediments in the Dry Valleys, of glacial landforms, drift deposits and raised beaches along
Victoria Land, as well as from ornithogenic soils in both presently occupied and abandoned penguin rookeries (Stuiver et al. 1981, Denton et al. 1989, 1991, Clapperton \& Sugden 1990, Baroni \& Orombelli 1991,1994a, Orombelli et al. 1991, Hall 1997). According to Stuiver et al (1981) the LGM in the Dry Valleys culminated between 24000 and $17000 \mathrm{yr} B \mathrm{P}$, and numerous ${ }^{14} \mathrm{C}$ dates of glacial lacustrine sediments in Taylor Valley date were taken to indicate deglaciation between c. 16000 and 13000 yr BP (Stuiver et al. 1981, Denton et al. 1989). Denton et al. (1991) and new data by Hall (1997) now suggest that this has to be seriously revised, and that the LGM in Taylor Valley dates to $14600-12700 \mathrm{yr} \mathrm{BP}$, and ice was within a few hundred metres of its maximum position as late as $10800 \mathrm{yr} \mathrm{BP}$.

A number of ${ }^{14} \mathrm{C}$ dates constrain the marine-based ice sheet retreat in the Ross Sea from the LGM-grounding line after $17000 \mathrm{yr}$ BP. Minimum ages for the deglaciation of the area between $75^{\circ} \mathrm{S}$ and $76^{\circ} \mathrm{S}$ come from offshore sediments close to the present Drygalski ice tongue, and are c. $11400 \mathrm{yr}$ BP (Licht et al. 1996). At the LGM, the Terra Nova Bay region was occupied by coalescing outlet glaciers, draining the East Antarctic Ice Sheet and joining the marine based Ross Ice Sheet (Baroni \& Orombelli 1991, Orombelli et al. 1991). Glacial drift deposits related to the LGM indicate that the ice surface in the bay was about $400 \mathrm{~m}$ above the present sea 
level. Even though the grounding line of the ice sheet had retreated to south of Terra Nova Bay by $11400 \mathrm{yr}$ BP, the break-up of the shelf ice was probably considerably delayed. The minimum age for the deglaciation of Terra Nova Bay is some time before $6200 \mathrm{yr} \mathrm{BP}$, when the coasts there became free of ice and marine habitats could begin to develop (Baroni \& Orombelli 1991, Orombelli et al. 1991). The oldest penguin rookeries in the Bay date back to $5800 \mathrm{yr} \mathrm{BP}$.

Denton et al. 1991 and Hall (1997) date the presence of the

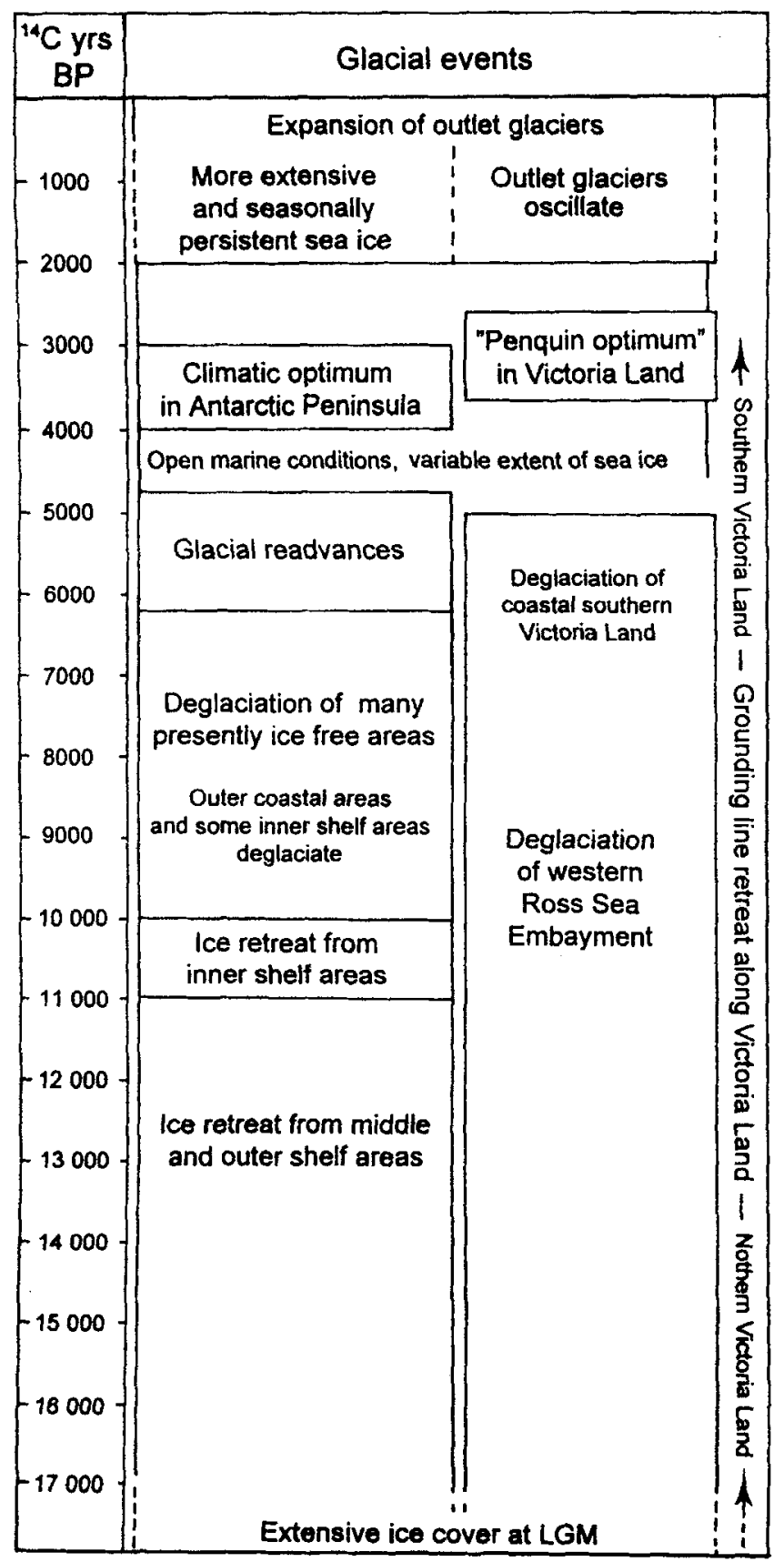

Fig. 9. Broad synthesis for Antarctic glacial and associated environmental development since the LGM.
Ross Sea Ice Sheet in Explorers Cove, southern Victoria Land, damming lakes along the valley threshold, at $8300 \mathrm{yr}$ BP. Date of penguin rookeries on Ross Island and in the McMurdo Sound area give minimum ages for the deglaciation in the southern Ross Sea. Rookeries at Cape Bird were occupied by 6800-5700 yr BP (Speir \& Cowling 1984, Heine \& Speir 1989). Marine fossils collected from debris bands on the McMurdo Ice Shelf date the grounding line recession of the Ross Sea ice sheet to a position south of Black Island by $6300 \mathrm{yr}$ BP (Kellogg et al. 1990), which is in line with the penguin data. ${ }^{14} \mathrm{C}$ dates on fossil marine molluscs from raised beaches along the southern Victoria Land coast, McMurdo Sound and the islands in the south-westem Ross Sea, as well as additional dates on penguin occupation in McMurdo Sound, all give minimum ages for the deglaciation as $c .6300$ 6100 yr BP (Stuiver et al. 1981, Speir \& Cowling 1984, Denton et al. 1989, Colhoun et al. 1992, Baroni \& Orombelli 1994a, Kellogg et al. 1996). A relative sea-level curve for the coast north of Explorers Cove indicates unloading of grounded ice by $6300 \mathrm{yr} \mathrm{BP}$ and provides one minimum estimate for the deglaciation of coastal southern Victoria Land (Hall 1977). It coincides well with the oldest ${ }^{14} \mathrm{C}$ date on a bivalve from a core in McMurdo Sound, which gives $6500 \mathrm{yr}$ BP as the minimum age of grounding line retreat from this area (Licht et cl. 1996). The marine limit becomes gradually younger southwards, which might indicate lagging of shelf ice recession behind grounding line recession. The age of the marine limit is $6200 \mathrm{yr}$ Bp in Terra Nova Bay, $5400 \mathrm{yr}$ BP at Marble Point/ South Stream and $5000 \mathrm{yr}$ BP in the Explorers Cove area (Stuiver et al. 1981, Denton et al. 1989, Orombelli et al. 1991, Berkman 1997, Hall 1997).

Bockheim et al. (1989) concluded that Holocene icesurface lowering of the Hatherton Glacier in the Transantarctic Mountains, corresponding in time with grounding line recession in the south-western Ross embayment, occurred before c. $5300 \mathrm{yr}$ BP. Numerous ${ }^{14} \mathrm{C}$ dates on marine macrofossils recovered from dirt bands in shelf ice in southern McMurdo Sound indicate that the grounding line had retreated to an unknown position south of Minna Bluff by $2700 \mathrm{yr} \mathrm{BP}$ (Kellogg et al. 1990). It is not known when the McMurdo Ice Shelf attained its present grounding line position, and also unknown is whether the grounding line is presently stable, advancing or retreating (Kellogg et al. 1996).

There is some information available on mid-to late-Holocene glacier variations in Victoria Land. After the deglaciation in Terra Nova Bay, the ice shelves entering the bay were less extensive than today (Orombelli et al. 1991, Baroni 1994, Baroni \& Orombelli 1994b). The ice margins stood 2-5 km inside their present margins between 6200 and $5300 \mathrm{yr} \mathrm{BP}$. A readvance across raised beaches took place some time after 5300 yr BP (Baroni \& Orombelli 1994b). There was then a renewed withdrawal phase between c. 1000 and $500 \mathrm{yr} \mathrm{BP}$, correlated by Baroni (1994) and Baroni \& Orombelli (1994b) with the Northern Hemisphere Medieval Warm Period (c. 1000-1300 AD). Moraine ridges containing fossil marine 
shells then show a glacial readvance in Terra Nova Bay after 500 yr BP, which Baroni \& Orombelli (1994b) suggested might correspond to the Little Ice Age glacial expansion in the Northern Hemisphere. Möller (1995) described a system of minor, fresh-looking thrust moraines in Granite Harbour, Victoria Land, which he suggested were formed by repeated oscillations during general retreat of the ice front. The youngest thrust moraine post-dates $1910 \mathrm{AD}$, when the British Terra Nova Expedition surveyed the area, and Möller (1995) concluded that the moraine ridge system was formed in connection with a Little Ice Age glacial expansion.

Alpine glaciers in the Dry Valleys probably did not contribute to the Ross Sea Ice Sheet, and some of these are presently at their maximum frontal positions since the LGM (Stuiver et al. 1981). The Wilson Piedmont Glacier in southern Victoria Land was contiguous with the Ross Ice Sheet at the LGM (Hall 1997) and merged with it north of Explorers Cove (Fig. 8). The Wilson Piedmont glacier retreated inside the coast between 5700 and 5000 yr BP (Hall 1997). It readvanced in late Holocene times, and at a number of locations it advanced across raised beaches which date back to $5400-$ 5000 yr BP (Nichols 1968, Stuiver et al. 1981, Denton et al. 1989, Hall 1997).

The best information on palaeoclimatic development in Victoria Land during the latter part of the Holocene comes from the spatial and temporal distribution of penguin rookeries (Baroni \& Orombelli 1994a). The location of Adélie penguin colonies is determined by a number of climate-dependent factors, such as availability of ice-free coastal areas suitable for nesting, absence of persistent ice-foot, access to open water during the nesting season and the availability of food. Baroni \& Orombelli (1994a) documented the continuous presence of Adélie penguins after c. $7000 \mathrm{yr}$ BP, but the greatest diffusion of rookeries occurred between 3600 and $2600 \mathrm{yr} \mathrm{BP}$. They termed this interval the "penguin optimum", and concluded that it was a period of particularly favourable environmental conditions. It was followed by a sudden decrease in the number of penguin rookeries shortly after $2600 \mathrm{yr} \mathrm{BP}$, particularly in southern Victoria Land, attributed to an increase in sea ice. A mid-late Holocene decrease in sea ice and longer seasons with open water in southern Victoria Land is supported by the observations of Nichols (1968). He described raised beaches, clearly of high-energy type, at many sites south of Granite Harbour. At many of these sites today the ice-foot rarely breaks up and recent beaches are of low-energy type. All beaches described by Nichols (1968) are younger than $5400 \mathrm{yr}$ BP (Stuiver et al. 1981, Berkman 1997). Abandoned Adélie penguin rookeries, occupied during the penguin optimum, occur at Cape Ross and Marble Point (Baroni \& Orombelli 1994a), where Nichols (1968) described high energy beach ridges. The raised beach deposits at Marble Point have been dated to $5400 \mathrm{yr}$ вP (Stuiver et al. 1981, Berkman 1997).

\section{Summary}

Antarctic glaciers range in size from continental ice sheets to small outlet glaciers, with varied sensitivity and response time to climatic and other environmental changes. However, a broad pattern can be discerned in the glacial histories from the coastal sites around Antarctica discussed in this study (Fig. 9), from the LGM towards the present:

a) Ice extended offshore around most of Antarctica at the LGM, although some oases may have remained ice free.

b) Ice retreat from the LGM positions was under way by $17000-14000 \mathrm{yr} \mathrm{BP}$, and by $11000-10000 \mathrm{yr}$ BP initial deglaciation of some inner shelf areas as well as a few outer coastal land areas had occurred. The ice retreat from the LGM positions around Antarctica was probably eustatically controlled. Melting Northern Hemisphere glaciers caused global sea level to rise and Antarctic grounding lines and ice fronts gradually retreated from outer shelf areas towards the continent (Hollin 1962. Stuiver et al. 1981).

c) Deglaciation of some shallow inner shelf areas and of most presently ice-free land areas, with the exception of some East Antarctic oases, occurred between $c .10000$ $5000 \mathrm{yr}$ BP. After the receding glaciers had reached the edges of most of the presently ice free land areas or shallow inner shelf areas, by $10000-8000 \mathrm{yr} \mathrm{BP}$, the rate of deglaciation slowed considerably. It was not until $5000 \mathrm{yr}$ BP that most Antarctic glaciers had retreated to, or behind, their present positions.

d) Mid-Holocene glacial readvances are described from several areas around Antarctica. These are mostly dated by maximum ages only, but on James Ross Island in the Weddell Sea the glacial readvance culminated between 5000 and $4500 \mathrm{yr}$ BP and in the Bunger Hills in East Antarctica between $6200-4700 \mathrm{yr}$ BP.

e) Although the initial phase of deglaciation in Antarctica, up to $10000 \mathrm{yr}$ BP was probably controlled by the global sea level rise, the slower phase of gradual deglaciation between 10000 and $5000 \mathrm{yr}$ BP was most likely controlled by gradual interglacial warming in Antarctica. This warming seems to have been temporarily halted by a cooling spell between $6500-4700 \mathrm{yr} \mathrm{BP}$, reflected in the mid-Holocene glacial readvances and also documented in some lake- and marine records. The renewed warming thereafter peaked in a hypsithermal event, visible in the records between 4700 and $2000 \mathrm{yr}$ BP. The best documented records put it between 4000 and $3000 \mathrm{yr} \mathrm{sP}$, in the Antarctic Peninsula region, and between 3600 and 2600 yr BP in coastal Victoria Land. Many records indicate less sea ice in coastal areas and higher beach energies than at present in the mid-Holocene, which probably coincides with this relatively warm event. It also roughly correlates in time with peak summer 
insolation in the south (Budd \& Smith 1987, Budd \& Rayner 1990).

f) The hypsithermal event was followed by a general cooling. Outlet glaciers have expanded around Antarctica for the past $c$. 500 years. Goodwin (in press) suggested that late Holocene Antarctic ice-volume expansion might be equivalent to a $c .1 \mathrm{~m}$ global sea level lowering.

\section{Acknowledgements}

The authors acknowledge the generous support 'received from their respective national Antarctic research programs. P. Quilty is thanked for comments and suggestions which improved the manuscript. The Swedish Natural Sciences Research Council finances the research position of Ó. Ingólfsson.

\section{References}

Adamson, D. \& Pickard, J. 1983. Late Quaternary ice movement across the Vestfold Hills, Antarctica. In Oliver, R.L., James, P.R. \& JAGO, J.B., eds. Antarctic earth science. Canberra: Australian Academy of Sciences, 465-469

Adamson, D. \& Pickard, J. 1986. Cainozoic history of the Vestfold Hills. In PICKARD, J., ed. Antarctic oasis: terrestrial environments and history of the Vestfold Hills. Sidney: Academic Press. 63-98.

Adamson, D.A., Mabin, M.C.G. \& LuLy, J.G. 1997. Holocene isostasy and late Cenozoic development of landforms including Beaver and Radok Lake basins in the Amery Oasis, Prince Charles Mountains. Antarctica. Antarctic Science, 9, 299-306.

ANderson, J.B., Brake, C.F. \& Myers, N.C. 1984. Sedimentation on the Ross Sea continental shelf, Antarctica. Marine Geology, 57, 295-333.

Anderson, J.B., Shipp, S.S., Bartek, L.R. \& Reid, D.E. 1992. Evidence for a grounded ice sheet on the Ross Sea continental shelf during the late Pleistocene and preliminary paleodrainage reconstruction Antarctic Research Series, 57, 39-62.

Andrews, J.T. 1992. A case of missing water. Nature, 358, 281

Augustinus, P.C., Gore, D.B., Leishman, M.R., Zwartz, D \& Colhoun. E.A. 1997. Reconstruction of ice flow across the Bunger Hills, East Antarctica. Antarctic Science, 9, 347-354.

Banfield, L.A.\& ANDERson, J.B. 1995. Seismic facies investigation of the Late Quaternary glacial history of Bransfield Basin, Antarctica. Antarctic Research Series, 68, 123-140.

Baron, C. 1994. Notes on late-glacial retreat of the Antarctic Ice Sheet and Holocene environmental changes along the Victoria Land coast. Memoirs of National Institute of Polar Research Special Issue, No. 50, 85-107.

Baroni, C. \& Orombelli, G. 1991. Holocene raised beaches at Terra Nova Bay, Victoria Land, Antarctica. Quaternary Research. 36, 157-177.

Baroni, C. \& Orombelli, G. 1994a. Abandoned penguin rookeries as Holocene paleoclimatic indicators in Antarctica. Geology, 22, 23-26.

Baroni, C. \& Orombelli, G. 1994b. Holocene glacier variations in the Terra Nova Bay area (Victoria Land, Antarctica). Antarctic Science. 6, 497-505.

Barret, P.J, Hambrey, M.J. \& Robinson, P.R. 1991. Cenozoic glacial and tectonic history from CIROS-1, McMurdo Sound. In THomson. M.R.A., Crame, J.A. \& Thomson, J.W., eds. Geological evolution of Antarctica. Cambridge: Cambridge University Press, 651-656.
Barsch, D. \& Mäusbacher, R. 1986. Beiträge zur Vergletscherungsgeschichte und zur Reliefentwicklung der Südshetland Insel. Zeitschrift für Geomorphologie, 61, 25-37.

Berkman, P. 1994. Geochemical signatures of meltwater in mollusc shells from Antarctic coastal areas during the Holocene. Memoirs of National Institute of Polar Research, Special Issue, No. 50, 11-27.

Berkman, P. 1997. Ecological variability in Antarctic coastal environments: past and present. In Battaglia, B., Valencia, J. \& WALTON, D.W.H., eds. Antarctic communities, structure and survival. Cambridge: Cambridge University Press, 349-357.

Berkman, P.A. \& Forman, S.L. 1996. Pre-bomb radiocarbon and the reservoir correction for calcarcous marine species in the Southern Ocean. Geophysical Research Letters. 23, 363-366.

Birkenmajer, K. 1981. Lichenometric dating of raised marine beaches at Admirality Bay, King George Island (South Shetland Islands, West Antarctica). Bulletin de l'Academie Polonaise des Sciences, 29, 119-127.

Birkenmajer, K. 1987. Oligocene-Miocene glaciomarine sequences of King George Island (South Shetland Islands), Antarctica. Palaeontologia Polonica, 49, 9-36.

Birkenmajer, K. 1991. Tertiary glaciation in the South Shetland Islands. West Antarctica: evaluation of data. In Thomson, M.R.A., Crame, J.A. \& Thomson, J.W., eds. Geological evolution of Antarctica. Cambridge: Cambridge University Press, 627-632.

Birkenmajer, K., Ochyra, R., Olsson, I.U. \& Stuchlik, L. 1985. MidHolocene radiocarbon dated peat at Admirality Bay, King George Island (South Shetland Islands), West Antarctica. Bulletin of the Polish Academy of Sciences, 33, 7-13.

Bjốrck, S., HJort, C., IngólfsSon, Ó.\& SKog, G. 1991 a. Radiocarbon dates from the Antarctic Peninsula region - problems and potential. Quaternary Proceedings, 1, 55-65.

Bjorck, S., Malmer, N., Hjort, C., Sandgren, P.. Ingolffson, Ó., Wallen, B., Smith R.I.L. \& Liedberg-JonsSon, B. 1991b Stratigraphic and paleoclimatic studies of a 5,500 years old moss bank on Elephant Island, Antarctica. Arctic and Alpine Research. 23, $361-374$

Bjorck, S., Sandgren, P. \& Zale, R. 1991c. Late Holocene Tephrochronology of the Northern Antarctic Peninsula. Quaternary Research, 36, 322-328

Bjorck, S., Hakansson, H. Zale, R., Karlen, W \& Liedberg-Jonsson, B. $1991 \mathrm{~d}$. A late Holocene lake sediment sequence from Livingston Island, South Shetland Islands, with paleoclimatic implications. Antarctic Science, 3, 61-72.

Biorck, S., Hakansson, H., Olsson, S., Barnekow, L. \& Jansens, J. 1993. Paleoclimatic studies in South Shetland Islands, Antarctica, based on numerous stratigraphic variables inlake sediments. Journal of Paleolimnology, 8, 233-272.

Biorck, S., Hakansson, H., Olsson, S., Ellis-Evans, C., Humlum, O. \& LiRIO, J.M. 1996a. Late Holocene palaeoclimatic records from lake sediments on James Ross Island, Antarctica. Palaeogeography, Palaeoclimatology, Palaeoecology. 113, 195-220.

Bjorck, S., Hjort, C., Ingólfsson, Ó., Zale, R. \& Ising, J. $1996 \mathrm{~b}$. Holocene deglaciation chronology from lake sediments. In LópEZMartinez, J., Thomson, M.R.A. et al., eds. Geomorphological map of Byers Peninsula, Livingston Island. BAS GEOMAP Series, Sheet 5-a, 1:25000, with supplementary text. Cambridge: British Antarctic Survey, $65 \mathrm{pp}$.

Bockheim, J.G., Wilson, S.C., Denton, G.H., Andersen, B.G. \& Stuiver, M. 1989. Late Quaternary ice-surface fluctuations of Hatherton Glacier, Transantarctic Mountains Quaternary Research, 31. 229-254.

Bolshiyanov, D.Y., Verkulich, S.R., Klokov, V., Makeev, V. \& Arslanov, H. 1990. Radiocarbon dating of sediments from the Bunger oasis (East Antarctica). In WAND, U. \& STRAuCH, G., eds. Proceedings of the Fifth Working Meeting lsotopes in Nature. Leipzig: Zentralinstitut fur Isotopenforschung, 47.52. 
Bolshiyanov, D., Verkulich, S., Pushina, Z. \& Kirienko, E. 1991. Some features of the Late Pleistocene and Holocene history of the Bunger Hills (East Antarctica). Abstracts Sixth International Symposium on Antarctic Earth Science. Tokyo: National Institute of Polar Research, 66-71.

BROECKER, W.S. 1963. Radiocarbon ages of Antarctic materials. Polar Record, 11, 472-473.

BRONGE, C. 1992. Holocene climatic record from lacustrine sediments in a freshwater lake in the Vestfold Hills, Antarctica. Geografiska Annaler, 74A, 47-58

Budd, W.F. \& RAYNer, P. 1990. Modelling global ice and climate changes through the ice ages. Annals of Glaciology, 14, 23-27.

BUDD, W.F. \& SMTr, 1.N. 1987. Conditions for growth and retreat of the Laurentide Ice Sheet. Geografia Fisica Dinamica Quaternaria, 41, 279-290

Burgess, J.S., Spate, A.P. \& Shevlin, J. 1994. The onset of deglaciation in the Larsemann Hills, Eastern Antarctica. Antarctic Science, 6 , 491-495

Burgess, J., Carson, C., Head, J. \& Spate, A. 1997. Larsemann Hills: not heavily glaciated during the Last Glacial Maximum. In Riccı, C., ed. The Antarcitic region: geological evolution and processes. Siena: Museo Nazionale dell' Antartide, 841-843.

Cameron, R.L., Loken, O. \& Molholm, J. 1959. Wilkes Station glaciological data 1957-58. Ohio State University Research Foundation Report, 825-1, $173 \mathrm{pp}$.

Clapperton, C.M. 1990. Quaternary glaciations in the Southern Ocean and Antarctic Peninsula area. Quaternary Science Reviews, 9, 229-252.

Clapperton, C.M. \& Sugden, D.E. 1982. Late Quaternary glacial history of George V1 Sound area, West Antarctica. Quaternary Research, 18, 243-267.

Clapperton, C.M.\& Sugden, D.E. 1988. Holocene glacier fluctuations in South America and Antarctica. Quaternary Science Reviews, 7 , 185-198.

Clapperton, C.M. \& Sugden, D.E. 1990. Late Cenozoic glacial history of the Ross embayment, Antarctica. Quaternary Science Reviews, 9, 253-272.

Clark, J.A. \& Lingle, C.S. 1979. Predicted sea-level changes $(18,000$ years BP to present) caused by late-glacial retreat of the Antarctic Ice Sheet. Quaternary Research, 9, 265-287.

Colmoun, E.A. 1997. A review of geomorphological research in Bunger Hills and expansion of the East Antarctic ice sheet during the Last Glacial Maximum. In RICCI, C., ed. The Antarctic region: geological evolution and processes. Siena: Museo Nazionale dell' Antartide, 801-807.

Colmoun, E.A. \& Adamson, D.A. 1991. Raised beaches of the Bunger Hilis. In Gillieson, D. \& Fitzsimons, S., eds. Quaternary research in Australian Antarctica: future directions. Special Publication No.3. Canberra: Department of Geography and Oceanography, University College, Australian Defence Force Academy, 79-84.

Colmoun, E.A.\& Adamson, D.A. 1992a. The Quaternary history of the Bunger Hills, East Antarctica. In Yoshida, Y., Kaminuma, K. \& SHIRAISHI, K., eds. Recent progress in Antarctic earth science. Tokyo: Terra Scientific Publishing Company, 745-750.

Colmoun, E.A. \& Adamson, D.A. 1992b. Raised beaches of the Bunger Hills. Australian National Antarctic Research Expedition Report, 136, $47 \mathrm{pp}$

Colmoun, E.A., Mabin, M.C.G., Adamsson, D.A.\& Kirk, R.M. 1992. Antarctic ice volume and contribution to sea-level fall at $20,000 \mathrm{yr}$ BP from raised beaches. Nature, 358, 316-319.

CURL, J.E. 1980. A glacial history of the South Shetland Islands, Antarctica. Ohio State University, Institute of Polar Studies Report, No. 63, $129 \mathrm{pp}$

Denton, G.H. 1979. Glacial history of the Byrd-Darwin Glacier area, Transantarctic Mountains. Antarctic Journal of the United States, 14(5), 57-58.
Denton, G.H., Bockheim, J.G., Wilson, S.C. \& Stuiver. M. 1989 Late Wisconsin and Early Holocene glacial history. inner Ross Embayment, Antarctica. Quatemary Research, 31. 151-182.

Denton, G.H., Prentice, M.L. \& Burckle, L.H. 1991, Cainozoic history of the Antarctic ice sheet. In TINGEY, R.J., ed. Geology of Antarctica. Oxford: Oxford University Press, 365-433.

Domack, E.W. 1992. Modern carbon-14 ages and reservoir corrections for the Antarctic Peninsula and Gerlache Strait area Antarctic Journal of the United States. 27(5), 63-64.

Domack, E.W., Jull, A.J.T. \& Donahue, D.J. 1991a. Holocene chronology for the unconsolidated sediments at Holc 740A: Prydz Bay, East Antarctica. In Barron, J. Larsen, B. et al. Proceedings of the Ocean Drilling Program Scientific Results, 119, 1-7.

DoMack, E.W., Jull, A.J.T. \& Nako, S. 199lb. Advance of East Antarctic oullet glaciers during the Hypsithermal: implications for the volume state of the Antarctic ice sheet under global warming. Geology, 19, 1059-1062.

Domack, E.W., Ishman, S.E., Stein. A.B., McClennen, C.E. \& Tull, A.J.T. 1995. Late Holocene advance of the Müller Ice Shelf. Antarctic Peninsula: sedimentological, geochemical and palaeontological evidence. Antarctic Science, 7, 159-170.

Domack, E.W., Jull, A.J.T., ANDerson, J.B., Linick, T.W.\& WIIllams, C.R. 1989. Application of Tandem Accelerator Mass-spectrometer dating to Late Pleistocene-Holocene sediments of the East Antarctic Continental Shelf. Quaternary Research, 31, 277-287.

DreWry, D.J. 1979. Late Wisconsin reconstruction for the Ross Sea region, Antarctica. Journal of Glaciology. 24. 231-244.

DREWRY, D.J., JoRDAN, S.R. \& JANKowski, E. 1982. Measured properties of the Antarctic ice sheet: Surface configurations, ice thickness, volume and bedrock characteristics. Annals of Glaciology. 3. $83-91$.

Elverhøl, A. 1981. Evidence for a late Wisconsin glaciation of the Weddell Sea. Nalure, 293, 641-642.

FENTON, J.H.C. 1980. The rate of peat accumulation in Antarctic moss banks. Journal of Ecology, 68, 211-228.

FENTON. J.H.C. 1982. The formation of vertical edges on Antarctic moss peat banks. Arctic and Alpine Research. 14, 21-26.

Futzsimons, S.J. 1997. Depositional models for moraine formation in East Antarctic coastal oases. Journal of Glaciology, 43, 256-264.

Fitzsimons, S.J. \& Colmoun, E.A. 1995. Form, structure and stability of the margin of the Antarctic ice sheet, Vestfold Hills and Bungcr Hills, East Antarctica. Antarctic Science, 7, 171-179.

Fitzsimons, S.J. \& Domack, E.W. 1993. Evidence for early Holocene deglaciation of the Vestfold Hills, Antarctica. Polar Record, 29, 237-240.

Gillieson, D.S. 1991. An environmental history of two freshwater lakes in the Larsemann Hills, Antarctica. Hydrobiologia, 214 327-331.

Gingele, F., Kuhn, G., Maus, B., Melles, M. \& Schone, T. 1997 Holocene ice retreat from the Lazarev Sea shelf, East Antarctica Continental Shelf Research, 17. 137-163.

Goodwin, I.D. 1993. Holocene deglaciation, sea-level change, and the emergence of the Windmill Islands, Budd Coast, Antarctica Quaternary Research, 40, 70-80.

Goopwin, I.D. 1996. A mid to late Holocene readvance of the Law Dome ice margin, Budd Coast, East Antarctica. Antarctic Science, 8, 395-406

GoodwIN, I.D. in press. Did changes in Antarctic ice volume influence late Holocene sea-level lowering? Quaternary Science Reviews, 17

Gordon, J.E. \& Harkness, D.D. 1992. Magnitude and geographic variation of the radiocarbon content in Antarctic marine life implications for reservoir corrections in radiocarbon dating Quaternary Science Reviews, 11, 697-708

HALL, B.L. 1997. Geological assessment of Antarctic ice Sheet stability. Ph.D. thesis, University of Maine, Orono, $324 \mathrm{pp}$ [unpublished]. 
Hambrey. M.J. Iarsen, B. \& Ehrmann, W.U. 1989. Forty million years of Antarctic giacial history yielded by Leg 119 of the Ocean Drilling Program. Polar Record, 25, 99-106.

Hansom, J.D. \& FLint, C.P. 1989. Holocene ice fluctuations on Brabant Island, Antarctic Peninsula. Antarctic Science, 1, 165-166.

Harris, P.T., Howard, W., O'Brien, P.E., Sedgwick, P.N.\& Sikes, E.L. in press. Quaternary Antarctic ice-sheet fluctuations and Southern Ocean palaeoceanography: natural variability studies at the Antarctic CRC. AGSO Journal of Australian Geology and Geophysics, 20.

HaYAshi, M. \& Yoshida, Y. 1994. Holocene raised beaches in the Lutzow-Holm Bay region, East Antarctica. Memoirs of National Institute of Polar Research Special Issue, No. 50, 49-84

Heine, J.C. \& Speir, T.W. 1989. Ornithogenic soils of the Cape Bird Adélie penguin rookeries, Antarctica. Polar Brology, 10, 89-99.

HERRON, M.J.\& ANDERson, J.B. 1990 . Late Quaternary glacial history of the South Orkney Plateau, Antarctica. Quaternary Research, 33, 265-275.

Hiller, A. Wand, U., Kampf, H, \& Stackebrand, W. 1988. Occupation of the Antarctic continent by petrels during the past 35000 ycars: inferences from a ${ }^{14} \mathrm{C}$ study of stomach oil deposits. Polar Biology, 9, 69-77.

Hirakalya, K., Ono, Y., Hayashi, M., aniya, M., Iwata, S., Fuminara, K., MorIwaKl, K.\& Yoshida, Y. 1984. Antarctic geomorphological map of Langhovde. Tokyo: National Institute of Polar Research, $63 \mathrm{pp}$.

HJort, C., Bjorck, S., Ingólfsson, Ó. \& Möller, P. in press. Holocene deglaciation and climate history of the northern Antarctic Peninsula region - a discussion of correlations between the Southern and Northern Hemispheres. Annals of Glaciology.

Hiort. C.. Ingolfsson, Ó., Móller, P. \& Lirio, J.M. 1997. Holocene glacial history and sea-level changes on James Ross Island, Antarctic Peninsula. Journal of Quaternary Science, 12, 259-273.

HolLin, J.T. 1962. On the glacial history of Antarctica. Journal of Glaciology, 4, 173-195.

Hughes, T.J. 1975. The West Antarctic Ice Sheet: instability, disintegration and the initiation of ice ages. Reviews of Geophysics and Space Physics, 15, 1-46.

Hughes, T.J., Denton, G. H., Andersen, B.G., Schllling, D. H., Fastook, J.L. \& Lingle, C.S. 1981. The last great ice sheets: a global view. In Denton, G.H. \& Hughes, T.J., eds. The Last Great Ice Sheets. New York: John Wiley and Sons, 263-317.

Igarashi, A., Harada, N. \& Moriwaki, K. I995. Marine fossils of $30-40 \mathrm{~m}$ raised beach deposits and late Pleistocene glacial history around Lutzow-Holm Bay, East Antarctica. Proceedings NIPR Symposium on Antarctic Geosciences, 8, 219-229.

INGólfsson, Ó., Huort, C., BJorck, S. \& SMITh, R.I.L. 1992. Late Pleistocene and Holocene glacial history of James Ross Island, Antarctic Peninsula. Boreas, 21, 209-222.

JoHn, B.S. 1972. Evidence from the South Shetland lslands toward a glacial history of West Antarctica. Institute of British Geographers, Special Publication, No. 4, 75-89.

John, B.S. \& Sugden, D.E. 1971. Raised marine features and phases of glaciation in the South Shetland Islands. British Antarctic Survey Bulletin, No. 24, 45-111

Johnson, C.G. \& Vestat, J.R. 1991. Photosy thetic carbon incorporation and turnover in Antarctic cryptoendolithic microbial communities: are they the slowest-growing communities on Earth? Applied and Environmental Microbiology, 57, 2308-2311.

JoNsson, S. 1988. Observations on physical geography and glacial history of the Vestfjella nunataks in western Dronning Maud Land, Antarctica. Naturgeografiska Institutionen, Stockholms Universitet, Rapport, 68, $57 \mathrm{pp}$

Kélogg, T.B., Kellogg, D.E. \& Stuiver, M. 1990. Late Quatemary history of the southwestern Ross Sea: evidence from debris bands on the McMurdo Ice Shelf, Antarctica. Antarctic Research Series, 50, 25-56.
Kellogg, T.B., Hughes, T. \& Kellogg, D.E. 1996. Late Pleistocene interactions of East and West Antarctic ice-flow regimes: evidence from the McMurdo Ice Shelf. Journal of Glaciology, 42,486-500

Licht, K.J., Jennings, A.E., Andrews, J.T.\& Will.lams, K.M. 1996 Chronology of the late Wisconsin ice retreat from the western Ross Sea, Antarctica. Geology, 24, 223-226.

LINDSAY, D. 1973. Estimates of lichen growth rates in the maritime Antarctic. Arctic and Alpine Research, 54, $341-346$,

LinTINEN, P.\& NenONEn, J. 1997. Glacial history of the Vestfjella and Heimefrontfjella nunatak ranges in western Dronning Maud Land, Antarctica. In Ricci, C., ed. The Antarctic region: geological evolution and processes. Siena: Museo Nazionale dell Antartide, 845-852.

Lopez-Martinez, J., Thomson, M.R.A., Arche, A., Bjórck, S., EllisEvans, J.C., Hathway, B., Hernandez-Cifuentes, F., Huort, C.. ingolfsson, Ó. Ising, J., Lomas, S., Martinfz de Pisón, E.. Serrano. E., ZALE, R. \& KinG, S. 1996. Geomorphological map of Byers Peninsula, Livingston Island. BAS GEOMAP Series, Sheel 5 -a. 1:25 000, with supplementary text. Cambridge: British Antarctic Survey, $65 \mathrm{pp}$

Lovering, J.F. \& Prescott, J.R.V. 1979. Last of lands - Antarctica Melboume: Melboume University Press, $230 \mathrm{pp}$.

Mabin, M.C.G. $1985 .{ }^{14} \mathrm{C}$ ages for "Heroic Era" penguin and seal bones from Inexpressible Island. Terra Nova Bay, North Victoria Land. New Zealand Antarctic Record, 6(2), 24-25.

Mabin, MC.G. 1986. The Ross Sea section of the Antarctic ice sheet at 18,000 yr BP: evidence from Holocene sea-level changes along the Victoria Land coast. South African Journal of Science, 82, 506-508.

Maemoku, H. Miura, H. Salgusa, S. \& Moriwakı. K. 1997 Stratigraphy of Late Quaternary raised beach deposits in the northern part of Langhovde, Lutzow-Holm Bay, East Antarctica. Proceedings NIPR Symposium on Antarctic Geosciences, 10, 178-186.

MAUSBACHER, R. 1991. Die Jungkvartäre Relief-und Klimageschichte im Bereich der Fildeshalbinsel, Süd-Shetland-Inseln. Antarktis. Heidelberger Geographische Arbeiten, 89, $207 \mathrm{pp}$.

Mausbacher. R. Múlekr, J. \& Schmidt, R. 1989. Evolution of postglacial sedimentation in Antarctic lakes. Zeitschrift für Geomorphologie. 33, 219-234

Martinez-Macchiavelio, J.C., Tatur, A., Servant-Vildary, S. \& DEL VALLE, R. 1996. Holocene environmental change in a marineestuarine-lacustrine sediment sequence, King George Island, South Shetland Islands. Antarctic Science, 8, 313-322.

MAYEWSKI, P.A. 1975. Glacial geology and late Cenozoic history of the Transantarctic Mountains, Antarctica. Ohio State University Institule of Polar Studies Report, No. 56, 1-168.

Melles, M. Verkulich, S.R \& Hermichen, W-D. 1994. Radiocarbon dating of lacustrine and marine sediments from the Bunger Hills, East Antarctica. Antarctic Science, 6, 375-378.

Melles, M., Kulbe, T., Verkulich, S.R., Pushina, Z.V. \& Hubberten, H. W. 1997. Late Pleistocene and Holocene environmental history of Bunger Hills, East Antarctica, as revealed by fresh-water and epishelf lake sediments. In Ricci, $\mathrm{C}$, ed. The Antarctic region: geological evolution and processes. Siena: Museo Nazionale dell' Antartide, 809-820.

Moriwaki, K., Yoshida, Y.\& Harwoon, D.M. 1992. Cenozoic glacial history of Antarctica - a correlative synthesis. In YosHiDA. Y., Kaminuma, K. \& Shiraishi, K., eds. Recent progress in Antarctic earth science. Tokyo: Terra Scientific Publishing Company, $773-780$.

MOLleR, P. 1995. Subrecent moraine ridge formation on Cuff Cape, Victoria Land. Antarctica. Geografiska Annaler, 77A, 83-94.

Nichols, R.L. 1968. Coastal geomorphology, McMurdo Sound, Antarctica. Journal of Glaciology, 7, 449-478

Nienow, J.A. \& Friedmann, E.1. 1993. Terrestrial lithophytic (rock) communities. In FrIEDMANN, E.l., ed. Antarctic microbiology. New York: John Wiley \& Sons, 343-412. 
Oмото. K. 1977. Geomorphic development of the Sôya Coast, East Antarctica. Science Reports of Tohoku University, $7^{\text {th }}$ Series, 27. $95-148$

OMOTO, K. 1983. The problem and significance of radiocarbon geochronology in Antarctica. In OLIVER, R.L, James, P.R. \& Jago, J.B., eds. Antarcticearth science. Cambridge: Cambridge University Press, 205-209

Orombelli, G., Baroni, C. \& Denton, G.H. 1991, Late Cenozoic glacial history of the Terra Nova Bay region, Northern Victoria Land, Antarctica. Geografia Fisica Dinamica Quaternaria, 13, $139-163$.

Payne, A.J.D., Sugden, D.E. \& Clapperton, C.M. 1989. Modelling the growth and decay of the Antarctic Peninsula ice sheet. Quaternary Research, 31, 119-134.

Pickard, J. 1982. Holocene winds of the Vestfold Hills, Antarctica. Vew Zealand Journal of Geology and Geophysics, 25, 353-358

PICKARD, J. 1985. The Holocene fossil marine macrofauna of the Vestfold Hills, East Antarctica. Boreas, 14, 189-202.

PICKARD, 3. \& Seppelt, R.D. 1984. Holocene occurrence of the moss Bryum algens Card. in the Vestfold Hills, Antarctica. Journal of Bryology, 13, 209-217.

Pickard, 1., ADAmSON, D.A. \& Heath, C.W. 1986. The evolution of Watts Lake, Vestfold Hills, East Antarctica, from marine inlet to ireshwater lake. Palaeogeography, Palaeoclimaiology. Palaeoecology, 53, 271-288

Pickard, J., Selkirk, P.M. \& Selkirk, D.R. 1984. Holocene climates of the Vestfold Hills, Antarctica and Macquarie Island. In VoGEL, J.C., ed Late Cainozoic Pale oclimates of the Southern Hemisphere. Rotterdam: A.A. Balkema, 173-182.

POPE, P.G. \& ANDERSON, J.B. 1992. Late Quaternary glacial history of the northern Antarctic Peninsula's western continental shelf: evidence from the marine record. Antarctic Research Series, 57, 63-91.

Pudsey, C.J., Barker, P.F. \& Larter, R.D. 1994. Ice sheet retreat from the Antarctic Peninsula Shelf. Continental Shelf Research, 14, $1647-1675$

Quitiy, P.G. 1992. Late Neogene sediments of coastal East Antarctica. In Yoshida, Y., Kaminuma, K. \& ShlRAishi, K, eds. Recentprogress in Antarctic earth science. Tokyo: Terra Scientific Publishing Company, 699-705.

RiChter, W \& Bormann, P. 1995. Geomorphology, In Bormann, P. \& Fritzsche, D., eds. The Schirmacher Oasis, Queen Maud Land, East Antarctica, and its surroundings. Gotha: Justus Perthes Verlag, $171-190$

RABASSA, J 1983. Stratigraphy of the glacigenic deposits in northern James Ross Island, Antarctic Peninsula. In Evenson, E., Sclochter, C. \& RABASSA, J., eds. Tills and related deposits. Rotterdam: A.A. Balkema, 329-340.

ROBERTS, D \& MCMINN, A. 1996. Relationships between surface sediment diatom assemblages and water chemistry gradients in saline lakes of the Vestfold Hills, Antarctica. Antarctic Science, 8 , $331-341$

ROBERTS, D. \& MCMINN, A. in press: A weighted-averaging regression and calibration model for inferring lakewater salinity from fossil diatom assemblages in saline lakes of the Vestfold Hills: a new tool for interpreting Holocene lake histories in Antarctica. Journal of Paleolimnology.

RozYcki, S.Z. 1961. Changements Pleistocenes de l'extesion de l'Inlandis en Antactide Orientale d'après l'étude des anciennes plages élevées de l'Oasis Bunger, Queen's Mary Land. Biuletyn Peryglacjalny, 10, 257-283.

SAWAGAKl, T. \& HiRakawa, K. 1997. Erosion of bedforms by subglacial meltwater, Soya Coast, East Antarctica. Geografiska Annaler, 79(A), 223-238.

SChmot, R., Mausbacher, R. \& Muller, J. 1990. Holocene diatom flora and stratigraphy from sediment cores of two Antarctic lakes
(King George Island). Journal of Paleolimnology, 3, 55-74.

ShaCkleton, N.J. \& KenNETT, J.P. 1975. Paleotemperature history of the Cainozoic and the initiation of Antarctic glaciation: oxygen and carbon analyses in DSDP sites 277, 279 and 281. Initial Reports of the Deep Sea Drilling Project, 29, 743-755.

Shevenel., A.E., Domack, E.W. \& Kernan, G.M. 1996. Record of Holocene palaeoclimate change along the Antarctic Peninsula: evidence from glacial marine sediments, Lallemand Fjord. Papers and Proceedings of the Royal Society of Tasmania, 130, 55-64

SHIP, S.S. \& ANDERSON, J.B. 1994. High-resolution seismic survey of the Ross Sea continental shelf: implications for ice-sheet retreat behaviour. Antarctic Journal of the United States, 29(5), 137-138.

Speir, T.W. \& Cowling, J.C. 1984. Ornithogenic soils of the Cape Bird Adélie penguin rookeries, Antarctica 1. Chemical properties. Polar Biology, 2, 199-205.

Squyres, S.W., Andersen, D.W., Nedell, S.S. \& Wharton Jr, R.A. 1991. Lake Hoare, Antarctica: sedimentation through thick perennial ice cover. Sedimentology, 38, 363-379

StaCkebrandr, W, 1995. Moraines around lake Untersee-indicators of the Late Quaternary regional glacial history In BORMANN, P. \& Fritzsche, D., eds. The Schirmacher Oasis, Queen Maud Land East Antarctica and its surroundings. Gotha: Justus Perthes Verlag, 237-242.

Stulver, M. Denton, G-H.. Hlgihes, T.J. \& Fastook, J.L. 1981 History of the marine ice sheet in West Antarctica during the last deglaciation: a working hypothesis. In DENTON, G.H. \& HugHes T.J., eds. The Last Great Ice Sheets. New York: John Wiley. $319-436$.

Sugden, D.E. \& Clapperton, C.M. 1977. The maximum ice extent on island groups in the Scotia Sea. Antarctica. Quaternary Research. 7. 268-282

Sugden, D.E. \& Clapperton, C.M. 1981. An ice-shelf moraine, George IV Sound, Antarctica. Annals of Glaciology, 2, 135-141.

Sugden, D,E. \& JOHN, B.S. 1973. The ages of glacier fluctuations in the South Shetland Islands, Antarctica. In VAN Zinderen BAKKer. E.M., ed. Palaeoecology of Africa, the surrounding islands and Antarctica, vol. 8. Cape Town: Balkema, 141-159.

Sugden, D.E., Marchant, D.R. \& Denton. G.H. 1993. The case for a stable East Antarctic Ice Sheet: the background. Geografiska Annaler, 75A, 151-153

Verkulich, S.R. \& Melles, M. 1992. Composition and paleoenvironmental implications of sediment in a fresh water lake and in marine basins of Bunger Hills, East Antarctica. Polarforshung, 60, 169-180.

VERKULICH, S.R. \& HILlER, A. 1994. Holocene deglaciation of Bunger Hills revealed by ${ }^{14} \mathrm{C}$ measurements on stomach oil deposits in snow petrel colonies. Antarctic Science, 6, 395-399.

Vincent, W.F., Howard-Williams, C.\& Broady, P.A. 1993. Microbial communities and processes in Antarctic flowing waters. In FrIEDMAN. E.l., ed. Antarctic microbiology. New York: John Wiley, 543.569.

Weiss, R.F., Oesterlund, H.G. \& Craig. H. 1979. Gcochemical studies of the Weddell Sea. Deep-Sea Research, 26, 1093-1120.

Whitehouse, I.E., Chinn, T.J.H., von Hoefle, H.C. \& McSaveney, M.J. 1987. Radiocarbon contaminated penguin bones from Terra Nova Bay, Antarctica. New Zealand Antarctic Record, 8(3), 11-23.

Whitehouse, I.E., ChInN, T.J.H.\& von HoEfle, H.C. 1989. Radiocarbon dates from raised beaches, Terra Nova Bay, Antarctica. Geologisches Jarbuch, E38, $321-334$

WISNIEWSKI, E. 1983. Bunger Oasis: the largest ice-free area in the Antarctic. Terra, 95, 178-187.

YANG, S.Y.\& HARWOOD, D.M. 1997. Late Quaternary environmental fuctuations based on diatoms from Yanou Lake, King George Island, Fildes Peninsula, Antarctica. In RICCl, C., ed. The Antarctic region: geologicalevolution and processes. Siena: Museo Nazionale dell' Antartide, 853-859. 
Yoshida, Y, 1983. Physiography of the Prince Olav and the Prince Harald coasts, East Antarctica. Memoirs of National Institute of Polar Research, Series C, 13,83 pp.

Yoshida, Y. \& MORIWAKI, K. 1979. Some consideration on elevated coastal features and their dates around Syowa Station, Antarctica. Memoirs of National Institute of Polar Research, Special Issue, No. 13, 220-226.

YoshiKawa, T. \& ToYa, H. 1957. Report on geomorphological results of the Japanese Antarctic Research Expedition, 1956-57. Nankyoku Shiryou, 1, 1-13.
ZALE, R, 1994. ${ }^{14} \mathrm{C}$ age correction in Antarctic lake sediments inferred from geochenistry. Radiocarbon, 36, 173-185.

ZaI.E, R. \& KARLEN. W. 1989. Lake sediment cores from the Antarctio Peninsula and surrounding islands. Geografiska Annaler, 7I(A). $211-220$.

ZHANG, Q.S. 1992. Late Quaternary environmental changes in the Antarctic and their correlation with global change. In YosHida. $\mathrm{Y}$. Kaminuma, K. \& Shiraishi, K., eds. Recent progress in Antarctic earth science. Tokyo: Terra Scientific Publishing Company. $781-785$. 